\title{
Review \\ mTOR Signaling in the Inner Ear as Potential Target to Treat Hearing Loss
}

\author{
Maurizio Cortada ${ }^{1}\left(\mathbb{D}\right.$, Soledad Levano $^{1}$ and Daniel Bodmer ${ }^{1,2, *}$ \\ 1 Department of Biomedicine, University of Basel, Hebelstrasse 20, 4031 Basel, Switzerland; \\ maurizio.cortada@unibas.ch (M.C.); s.levano@unibas.ch (S.L.) \\ 2 Clinic for Otorhinolaryngology, Head and Neck Surgery, University of Basel Hospital, Petersgraben 4, \\ 4031 Basel, Switzerland \\ * Correspondence: Daniel.Bodmer@usb.ch; Tel.: +41-61-328-76-03
}

Citation: Cortada, M.; Levano, S.; Bodmer, D. mTOR Signaling in the Inner Ear as Potential Target to Treat Hearing Loss. Int. J. Mol. Sci. 2021, 22, 6368. https://doi.org/10.3390/ ijms22126368

Academic Editors: Anindita Das and Flávio Reis

Received: 20 May 2021

Accepted: 10 June 2021

Published: 14 June 2021

Publisher's Note: MDPI stays neutral with regard to jurisdictional claims in published maps and institutional affiliations.

Copyright: (c) 2021 by the authors. Licensee MDPI, Basel, Switzerland. This article is an open access article distributed under the terms and conditions of the Creative Commons Attribution (CC BY) license (https:// creativecommons.org/licenses/by/ $4.0 /)$.

\begin{abstract}
Hearing loss affects many people worldwide and occurs often as a result of age, ototoxic drugs and/or excessive noise exposure. With a growing number of elderly people, the number of people suffering from hearing loss will also increase in the future. Despite the high number of affected people, for most patients there is no curative therapy for hearing loss and hearing aids or cochlea implants remain the only option. Important treatment approaches for hearing loss include the development of regenerative therapies or the inhibition of cell death/promotion of cell survival pathways. The mammalian target of rapamycin (mTOR) pathway is a central regulator of cell growth, is involved in cell survival, and has been shown to be implicated in many age-related diseases. In the inner ear, mTOR signaling has also started to gain attention recently. In this review, we will emphasize recent discoveries of mTOR signaling in the inner ear and discuss implications for possible treatments for hearing restoration.
\end{abstract}

Keywords: cochlea; hair cells; hearing loss; inner ear; mTOR; protection; regeneration

\section{Introduction}

Sound waves that reach the external ear travel via the auditory canal to the eardrum, where vibrations are transmitted by the ossicles of the middle ear onto the inner ear at the oval window (Figure 1). The inner ear is a fluid-filled space, composed of the vestibular organ for the perception of balance and the spiral cochlea for auditory perception. Sound induced fluid waves in the cochlea lead to a deflection of stereocilia at the top of the hair cells, which are the auditory sensory cells (Figure 1). There are two types of hair cells in the cochlea: one row of inner hair cells (the actual sensory cells) and three rows of outer hair cells, which function as a signal amplifier (Figure 1). Deflection of the stereocilia leads to mechanoelectrical transduction: ion channels open and depolarize the hair cells. Ultimately, the depolarization of the inner hair cells leads to the secretion of glutamate at the inner hair cell synapses and to action potentials which propagate the signal via auditory nerve to the auditory cortex.

Defects at any of these levels, from the outer ear to the auditory cortex, can lead to hearing loss. Hearing loss with its cause in the outer or middle ear is classified as conductive hearing loss. Common causes are mechanical obstruction, infections, or malformations which can be surgically treated. Damage to the inner ear, auditory nerve, central auditory nuclei or cortex is classified as sensorineural hearing loss. Hair cells and their synapses are the most vulnerable structures and are commonly damaged or lost causing sensorineural hearing loss. Many exposures in life can lead to sensorineural hearing loss, such as noise, infections, or ototoxic drugs like aminoglycoside antibiotics and chemotherapeutic agents like cisplatin. Other causes are intrinsic, such as genetic susceptibility or aging. Due to their postmitotic nature, the hair cells do not regenerate upon loss in mammals. Consequently, the hair cells must be protected and preserved life-long. 


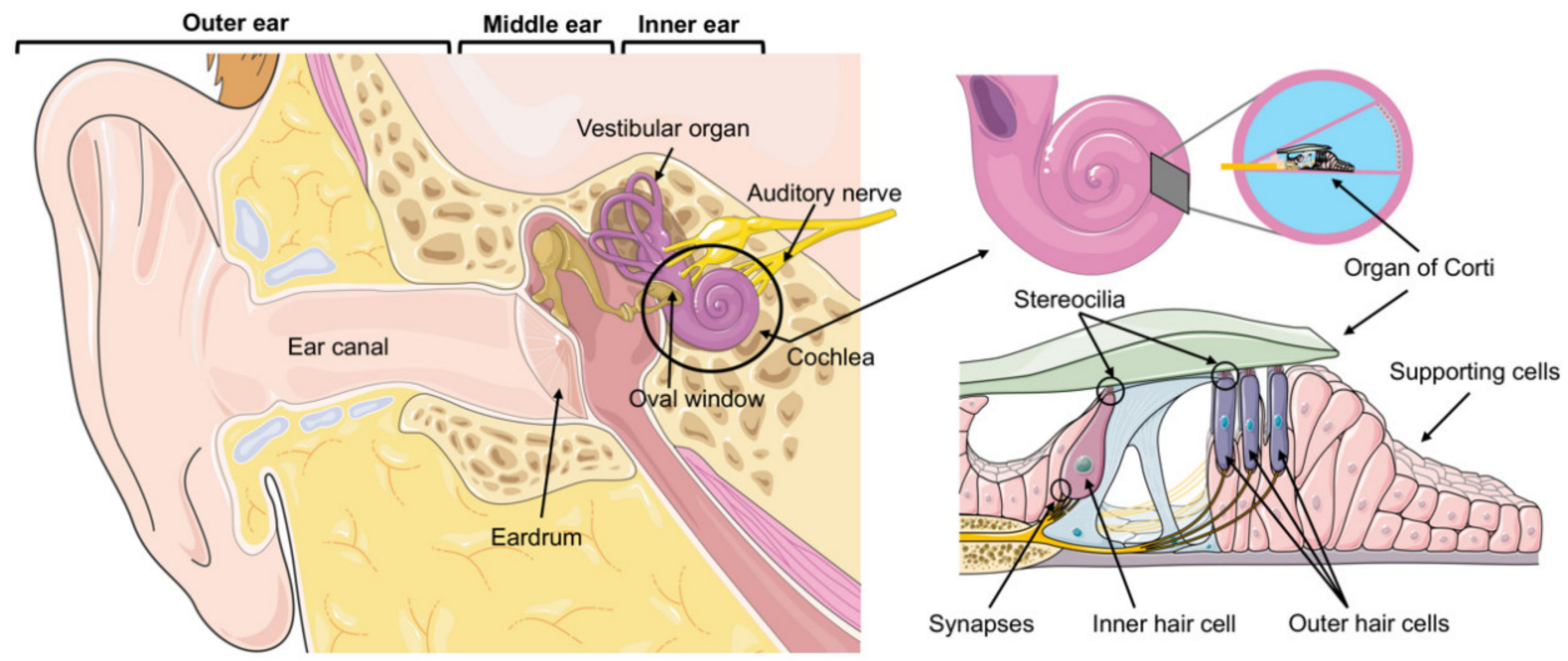

Figure 1. The anatomy of hearing. The spiral-shaped cochlea is the auditory sensory organ where mechanical sound waves are transmitted into electrical signals by the hair cells of the organ of Corti. See the text for further details. The figure was created with Servier Medical Art templates by Servier, which are licensed under a Creative Commons Attribution 3.0 Unported License; https: / / smart.servier.com (accessed on 16 January 2021).

Sensorineural hearing loss is considered to be the most frequent sensory deficit: According to WHO estimates, there are 466 million persons in the world suffering from disabling hearing loss [1]. One-third of the population $\geq 65$ years is affected by hearing loss [1]. With the increase in life expectancy and increasing number of elderly people in the population, the number of affected individuals will also increase. It is expected that by 2050, there will be over 900 million people suffering from hearing loss [1]. Despite these growing numbers, there are currently no curative therapies for sensorineural hearing loss. Current treatment options consist of hearing aids or cochlea implants for severely affected patients. In order to be able to cure hearing loss in the future, different strategies have been proposed: A potential cure for genetic forms of hearing loss could be gene therapy $[2,3]$. Another promising strategy is the use of stem cell or molecular therapies to restore the lost hair cells, and therefore treat hearing loss from various causes [2-4]. A further approach include pharmacological interventions which either inhibit cell death or promote cell survival pathways in sensory hair cells [3,4].

The mechanistic or mammalian target of rapamycin (mTOR) is a serine/threonine kinase which, as part of two multi-protein complexes, is a central cellular hub governing cell growth and cell survival among others [5]. It is an evolutionary conserved kinase, and its involvement in cancer, metabolic diseases, neurological and neurodegenerative diseases underlines its biological importance [6]. The drug rapamycin, which inhibits mTOR signaling led to the discovery of the TOR genes [7]. Rapamycin was the first drug for which a life-prolonging effect was shown in mammals [8]. Accordingly, the mTOR signaling pathway has been shown to play an important role in aging and age-related diseases [9]. Recently, mTOR signaling has also started to gain attention in the inner ear. In this review, we will highlight recent findings and discuss potential roles for hearing restoration.

\section{2. mTOR Signaling}

The mTOR kinase exists in in two distinct multi-protein complexes, which differ in composition, structure and function. They lie at the center of the mTOR signaling pathway and regulate distinct targets to exert their functions. In this section, we will introduce the major components of the mTOR signaling network. For deeper understanding of this pathway, we refer the readers to recent reviews [10-12]. 


\subsection{MTORC1}

The mTOR complex 1 (mTORC1) is the better studied of both complexes. Structurally, the complex is a homodimer composed of mTOR, the defining and essential subunit regulatory-associated protein of TOR (RAPTOR) and mammalian lethal with SEC13 protein 8 (mLST8) [13-16]. The mTORC1 is rapamycin sensitive: rapamycin inhibits mTORC1 after building a complex with FK506-binding protein of 12 KDa (FKBP12) $[17,18]$, possibly by blocking the access for substrates to the catalytic site [12]. Substrate recruitment by mTORC1 is accomplished in part via binding of RAPTOR to a TOR signaling (TOS) motif $[12,19,20]$.

Upstream activation of mTORC1 is regulated in form of an 'AND' gate [10], in that only when both growth factors and nutrients are available mTORC1 is activated. Upon ligand binding to receptor tyrosine kinases (RTKs) or G-coupled receptors (GPCRs), the receptors activate class I phosphoinositide 3-kinase (PI3K) family members which produce phosphatidylinositol $(3,4,5)$-tris- phosphate (PIP3) [21,22]. Inactive AKT is recruited to membranes by binding to PIP3 and is phosphorylated at Thr308 and Ser473 by phosphoinositide-dependent protein kinase 1 (PDK1) and mTOR complex 2 (mTORC2), respectively. This leads to AKT activation. Activated AKT inhibits the tuberous sclerosis complex (TSC) [23-25], which ends TSC-mediated inhibition of the RAS homolog enriched in brain (RHEB), finally activating mTORC1 [21,22]. The functional TSC consists of TSC1, TSC2, and Tre2-Bub2-Cdc16 (TBC) 1 domain family, member 7 (TBC1D7) [26]. In insulin/ insulin-like growth factor-1 (IGF-1) signaling, TSC2 is directly phosphorylated by AKT, which leads to the dissociation of the TSC from the lysosome [27] and disrupts the binding of TSC2 to TSC1 [23]. TSC2 has a guanosine triphosphatase (GTPase)-activating protein (GAP) activity towards RHEB [28]. Thereby, TSC stimulates the GTP hydrolysis of RHEB, converting this protein into an inactive GDP-loaded RHEB resulting in a decrease in mTORC1 activity [28]. With TSC inhibited by AKT, the active GTP-bound RHEB can activate mTOR on the lysosome $[10,29,30]$. In order for mTORC1 to be activated by RHEB, mTORC1 it needs to be recruited from the cytoplasm to the lysosome and this depends on the availability of amino acids, glucose and other nutrients [10]. Central to amino acid sensing are the Ras-related family of small GTPases (RAGs) [31,32], which localize to the lysosome via the RAGULATOR complex [33,34]. In response to amino acids, mTORC1 translocates to the lysosomal membrane and via RAPTOR directly binds to RAG-RAGULATOR complex [33,35]. The GAP activity towards the RAGs 1 (GATOR1) complex has a GAP activity to RAGs and therefore inhibits mTORC1 activity $[12,36,37]$. The GATOR1 complex itself is negatively regulated by GATOR2 [36]. The KICSTOR complex binds and translocates GATOR1 to the lysosomal surface and negatively regulates mTORC1 $[38,39]$. SESTRIN-2 has been discovered as the leucine sensor to the mTOR pathway [40]. SESTRIN-2 binds and blocks GATOR2 when leucine levels are low, whereas the binding of leucine to SESTRIN-2 blocks this interaction [40]. In arginine-depleted conditions, the cellular arginine sensor for mTORC1 (CASTOR1) binds and inhibits GATOR2 [41]. Folliculin (FLCN) is another amino acid sensor interacting directly with the RAGs [42,43]. The S-adenosylmethionine sensor upstream of mTORC1 (SAMTOR) binds to and promotes the mTORC1 inhibiting function of GATOR1 and KICSTOR [44]. This complex can be disrupted by S-adenosylmethionine (SAM) which is sensitive to methionine levels [44]. On the lysosome, there are additional proteins acting as amino acid sensors: the lysosomal vacuolar ATPase (v-ATPase) [45] and Solute carrier family 38 member 9 (SLC38A9) [46]. Amino acids are the best-known nutrients to activate mTORC1. However, apart from amino acids, other nutrients also activate mTORC1 [10,34]. The AMP-activated protein kinase (AMPK) senses cellular energy status and interacts in multiple ways with mTORC1 to inhibit its activity [12]. Interestingly, reactive oxygen species (ROS) have also been shown to either activate or inactivate mTORC1 [47-49] and mTORC1 has been shown to be redox sensitive [50-52].

Despite the important role mTORC1 plays in cells, there are not many direct downstream targets that have been identified to date. The most known direct targets are the ribo- 
somal S6 kinase (S6K), 4E binding protein 1 (4E-BP) and UNC-51-like kinase 1 (ULK1) [53]. In addition, mTORC 1 also acts via transcription factors such as transcription factor EB (TFEB) [54-56], activating transcription factor 4 (ATF4) [57] or hypoxia inducible factor $1 \alpha(\mathrm{HIF} 1 \alpha)[10,58]$. The general purpose of $\mathrm{mTORC} 1$ is to promote anabolic metabolism (protein, lipid and nucleotide synthesis) and to block the degrading catabolic processes (autophagy) [53]. mTORC1 promotes protein synthesis by activating and phosphorylating S6K on Thr389 and by an inhibitory phosphorylation on 4E-BP [10,12,53,59,60]. mTORC1 stimulates lipid synthesis via S6K or by inhibiting LIPIN1, which in turn activate sterol-regulatory element-binding protein (SREBP) $[53,58,61]$. Nucleotide synthesis is promoted by mTORC1 via ATF4 [57] or via S6K which further activates carbamoyl-phosphate synthetase 2, aspartate transcarbamoylase, dihydroorotase (CAD) enzyme [62,63]. mTORC1 also promotes glycolysis via HIF1 $\alpha$ and the pentose phosphate pathway via SREBP [58]. Interestingly, mTOR also enhances mitochondrial biogenesis via 4E-BP [64,65] or via transcription factor yin-yang 1 (YY1) and peroxisome-proliferator-activated receptor coactivator (PGC)-1 $\alpha$ coactivation [66]. To suppress catabolic processes, mTORC1 inhibits autophagy via inhibitory phosphorylations of ULK1 and autophagy-related gene (ATG) 13 protein [67-70]. mTORC1 also inhibits catabolism by phosphorylating and inhibiting TFEB, which promotes lysosomal biogenesis [54-56]. Table 1 summarizes the major mTORC1 signaling components.

Table 1. Overview of major mTORC1 signaling components discussed in the text and their corresponding functions.

\begin{tabular}{|c|c|c|}
\hline Protein(s)/Protein Complex & mTORC1 Signaling Related Function & References \\
\hline mTOR & Serine/threonine kinase that forms the catalytic subunit of mTORC1 & {$[10,71-73]$} \\
\hline mLST8 & mTORC1 subunit & {$[14,15]$} \\
\hline RAPTOR & Defining and essential subunit of mTORC1 & {$[15,16]$} \\
\hline FKBP12 & Forms a complex with rapamycin and inhibits mTORC1 & {$[17,18]$} \\
\hline AKT & Inhibits the TSC upon growth factor signaling & [23-25] \\
\hline $\begin{array}{c}\text { TSC1 } \\
\text { TSC2 } \\
\text { TBC1D7 }\end{array}$ & $\begin{array}{l}\text { Form the TSC which has GAP activity towards RHEB and therefore inhibits } \\
\text { mTORC1 }\end{array}$ & {$[26,28]$} \\
\hline RHEB & GTP-bound RHEB activates mTORC1 upon growth factor signaling & {$[28,29]$} \\
\hline RAG proteins & Signal amino acid availability to mTORC1 & {$[31,32]$} \\
\hline RAGULATOR complex & Binds the RAGs and is involved in amino acid signaling to mTORC1 & [33] \\
\hline GATOR1 complex & Negatively regulates RAGs to inhibit mTORC1 & [36] \\
\hline GATOR2 complex & Negatively regulates GATOR1 to activate mTORC1 & [36] \\
\hline KICSTOR complex & Translocates GATOR1 to the lysosome to negatively regulate mTORC1 & {$[38,39]$} \\
\hline SESTRIN-2 & Leucine sensor, inhibits mTORC1 by binding GATOR2 when leucine levels are low & [40] \\
\hline $\begin{array}{l}\text { CASTOR-1 } \\
\text { CASTOR-2 }\end{array}$ & Arginine sensors, inhibit mTORC1 by binding GATOR2 when arginine levels are low & [41] \\
\hline FLCN & Amino acid sensor positively regulating mTORC1 & {$[42,43]$} \\
\hline SAMTOR & $\begin{array}{l}\text { SAM (methionine) sensor, binds GATOR1 and KICSTOR to inhibit mTORC1 when } \\
\text { SAM/methionine levels are low }\end{array}$ & [44] \\
\hline v-ATPase & Lysosomal amino acid sensor & [45] \\
\hline SLC38A9 & Lysosomal amino acid sensor & [46] \\
\hline AMPK & $\begin{array}{l}\text { Senses cellular energy status and inhibits mTORC1 by different mechanisms when } \\
\text { cellular energy (ATP) is low }\end{array}$ & [12] \\
\hline S6K & mTORC1 effector, is phosphorylated and activated by mTORC1 to promote anabolism & {$[10,59]$} \\
\hline $4 \mathrm{E}-\mathrm{BP}$ & mTORC1 substrate, is phosphorylated and inhibited by mTORC1 to promote anabolism & {$[10,59,60]$} \\
\hline
\end{tabular}


Table 1. Cont.

\begin{tabular}{crrr}
\hline Protein(s)/Protein Complex & mTORC1 Signaling Related Function & References \\
\hline LIPIN1 & mTORC1 substrate, is phosphorylated and inhibited by mTORC1 to promote \\
lipid synthesis & [53,61] \\
\hline ATF4 & Is activated by mTORC1 to promote nucleotide synthesis & [57] \\
\hline HIF1 $\alpha$ & Is activated by mTORC1 to promote glycolysis & [58] \\
\hline ULK1 & mTORC1 substrate, is phosphorylated and inhibited by mTORC1 to inhibit autophagy & [67-69] \\
\hline ATG13 & mTORC1 substrate, is phosphorylated and inhibited by mTORC1 to inhibit \\
autophagy and lysosomal biogenesis & [12,54-56]
\end{tabular}

\section{2. $\mathrm{mTORC2}$}

In contrast to mTORC1, mTORC2 is rapamycin insensitive [74], however, it has also been shown to be inhibited by prolonged treatment with rapamycin [75]. mTORC2 is composed of mTOR, mLST8 [15], the rapamycin-insensitive companion of mTOR (RICTOR) [74,76] and MAPK-interacting protein 1 (mSIN1) [77-79]. mTORC2 structure resembles that of mTORC1 and exists in a homodimeric complex [80-82].

Growth factors are the best-known activators of mTORC2. Similarly to the activation of mTORC1, growth factors activate mTORC2 via the PI3K pathway, however, the precise mechanism remains elusive $[10,11]$. mSIN1 contains a pleckstrin homology $(\mathrm{PH})$ domain and it has been reported that this domain blocks mTORC2 activity, whereas PI3K activation releases this inhibition $[83,84]$. An alternative model is that mTORC2 lies permanently at the plasma membrane and is activated by AKT [11]. In addition to growth factors, mTORC2 has also been shown to be activated by small GTPases such as oncogenic Ras [85]; or by other signaling pathways, such as the Hippo pathway [86], the Wnt pathway [87] and its non-canonical planar cell polarity (PCP) pathway [88], and it is activated by AMPK [89] (all discussed in [11]). mTORC2 exists at different subcellular localizations, which might be differentially regulated [11]. Interestingly, an important pool seems to be located at the mitochondria and the mitochondria-associated endoplasmic reticulum (ER) membrane (MAM) (reviewed in [11,90]).

The main effectors and downstream targets of $\mathrm{mTORC} 2$ are protein kinase $\mathrm{A}, \mathrm{C}$ and G (AGC) family members [91]. The most studied target is AKT (protein kinase B, PKB) phosphorylated on Ser473 [92,93]. Furthermore, mTORC2 also phosphorylates AKT on Thr450 [94]. Other AGC family members regulated by mTORC2 are protein kinase C (PKC) $[15,74,76]$ and serum- and glucocorticoid-induced protein kinase 1 (SGK1) [95]. Interestingly, mTORC2 has also been shown to phosphorylate and inhibit the cystineglutamate antiporter $\mathrm{xCT}$, which is also known as Solute Carrier Family 7 Member 11 (SLC7A11) [96]. Table 2 summarizes the major mTORC2 signaling components.

Table 2. Overview of major mTORC2 signaling components discussed in the text and their corresponding functions.

\begin{tabular}{cccc}
\hline Protein & mTORC2 Signaling Related Function & References \\
\hline mTOR & Serine/threonine kinase that forms the catalytic subunit of mTORC2 & mTORC2 subunit & {$[10,71-73]$} \\
\hline mLST8 & mTORC2 subunit & {$[77-79]$} & {$[74,76]$} \\
\hline mSIN1 & Defining and essential subunit of mTORC2 & mTORC2 effector, phosphorylated and activated by mTORC2 & [92-94] \\
\hline RICTOR & mTORC2 effector, phosphorylated and activated by mTORC2, modulates the actin cytoskeleton & {$[15,74,76]$} \\
\hline AKT & mTORC2 effector, phosphorylated and activated by mTORC2 & [95] \\
\hline PKC & mTORC2 substrate, phosphorylated and inhibited by mTORC2 & {$[96]$} \\
\hline SLC7A11 & &
\end{tabular}




\subsection{Feedback Mechanisms}

There are also negative feedback loops between mTORC1 and mTORC2, which have been discussed as possible reasons for the lack of efficiency of rapamycin and its analogues to treat cancer [18]. mTORC1 has been shown to downregulate and inhibit the insulin receptor substrates (IRS) via S6K [97-99], therefore, negatively regulating insulin-PI3K-AKT and mTORC2 activation. Another feedback mechanism functions via growth factor boundreceptor protein 10 (GRB10): mTORC1 phosphorylates and stabilizes GRB10, which binds the insulin receptor and negatively regulates insulin-PI3K-mTORC2 signaling [100-102].

\section{3. mTOR Signaling in Auditory Sensory Hair Cell Regeneration}

It has long been postulated that the damage and death of the auditory sensory hair cells is the main underlying cause of hearing loss [103]. The functional principle of cochlea implants is also based on this notion, where implanted electrodes bypass the hair cells and stimulate the auditory nerve directly [104]. Studies by Kujawa and Liberman, however, have shown that especially in age-related and noise-induced hearing loss, an early loss of the hair cell innervating synapses occurs even before or without hair cell loss; a phenomenon named cochlear synaptopathy $[103,105,106]$.

It was long assumed that the postmitotic hair cells cannot regenerate upon loss [107]. However, since the discovery of hair cell regeneration in birds [108-111], a potential regenerative therapy to replace lost hair cells has come to the attention of researchers. This regeneration in birds emanates from the supporting cells that surround the hair cells in the organ of Corti (Figure 1). The mechanisms proposed are either mitotic regeneration or direct trans-differentiation of supporting cells to hair cells [112]. In contrast to birds, adult mammalian hair cells do not spontaneously regenerate once lost, and the loss of synapses in cochlear synaptopathy has also been shown to be mainly permanent [103]. Interestingly, supporting cells isolated from the cochlea of neonatal mice retain the ability to produce hair cells [113] and hair cell regeneration has been shown to some extent in the vestibular epithelium of mammals [114,115]. However, in the adult mammalian cochlea, lost hair cells are not regenerated.

An important approach to design hair cell regeneration therapies has been to study and exploit the signaling pathways and transcription factors involved in the development and maturation of hair cells [112]. Based on this rationale, a few compounds to treat hearing loss by regenerating lost hair cells are being tested in clinical trials: an adenoviral atonal homologue 1 (ATOH1, also known as Math1) gene therapy has been tested to treat hearing loss, but no major improvement in hearing or vestibular function has been found [116]. Atoh1 has been shown to be sufficient and necessary for auditory hair cell differentiation [117], and overexpression produces extra hair cells [118]. Other clinical studies use pharmacological approaches to induce hair cell regeneration: a NOTCH inhibitor [119] or the combination of a glycogen synthase kinase-3 (GSK3) inhibitor together with valproic acid, an antiepileptic drug [120], are being tested to treat sensorineural hearing loss. Unfortunately, no regenerative therapy has made it to the clinic to date.

Two early studies using rapamycin suggested the involvement of mTOR signaling in the proliferation of avian and mammalian sensory epithelia [121,122]. However, the role of mTOR signaling in cochlear hair cell regeneration has only recently started to be elucidated. Zheng-Yi Chen and colleagues have shown that the proliferation and regeneration of hair cells is indeed possible in the adult cochlea, both in vivo and in vitro [123]. By coactivating both $c-m y c(M y c)$ and Notch1 genes, they were able to induce the proliferation of both supporting cells and inner hair cells in adult cochleae [123]. Only when Myc and Notch1 were transiently activated in the cochlea, the supporting cells were able to respond to Atoh1 overexpression and trans-differentiate into hair cell-like cells [123]. These regenerated hair cells had functional transduction channels and even made contact with surrounding neurites [123]. Most interestingly, the authors detected strong labelling of the phosphorylated ribosomal S6 protein in newly proliferating supporting cells, which lies downstream of S6K and mTORC1. Moreover, rapamycin reduced then number of 
proliferating cells and the number of regenerated hair cell-like cells. By using MHY1485, a small molecule known to inhibit autophagy and activate mTOR [124], they also showed that mTOR partially compensates Myc function. Thus, the authors concluded that the mTOR pathway is involved in the proliferation and regeneration of cochlear hair cells [123].

Recent work by Li and Doetzlhofer has shown that the RNA binding protein LIN28B promotes the proliferation capacity and reprogramming of supporting cells to generate hair cells via the AKT-mTORC1 pathway [125]. The intrinsic ability of cochlear supporting cells to (re)generate hair cells is quickly lost during the first postnatal days. Already epithelial cells of postnatal day (P)5 mice fail to expand and produce hair cells [125]. Using both an organoid culture system and cochlear explant cultures from P5 transgenic mice overexpressing $\mathrm{Lin} 28 b, \mathrm{Li}$ and Doetzlhofer showed that organoids formed an increased number of hair cell clusters than the control organoids. The overexpression of Lin $28 b$ in organoids also stimulated the de-differentiation of supporting cells into prosensory-like cells with greater capabilities to generate hair cells. Overexpressing Lin28b in cochlear explants moreover increased the production of new hair cells by nonmitotic mechanisms. In contrast, the deletion of $\operatorname{Lin} 28 \mathrm{a} / \mathrm{b}$ or the overexpression of their inhibitor let-7 miRNA decreased the hair cell generation capabilities of supporting cells [125]. Most interestingly, both the phosphorylation of the S6 protein at Ser240/244 and AKT phosphorylation at Ser473 decreased during postnatal development in cochlear explants (in parallel with the decline in hair cell generation capabilities) [125]. Accordingly, the deletion of Lin28a/b or let-7 miRNA overexpression decreased the phosphorylation levels of AKT, S6, and $4 \mathrm{E}-\mathrm{BP}$ in neonatal mice cochleae and organoids. In contrast, higher phosphorylation levels of AKT and S6 have been detected in Lin28b overexpressing organoids than in control organoids [125]. Notably, rapamycin attenuated supporting cell proliferation and hair cell generation promoted by Lin $28 b$ overexpression in organoids and cochlear explants. These findings suggest that LIN28B controls supporting cell plasticity via the activation of mTOR signaling [125]. In summary, these recent studies indicate an important role of mTOR in hair cell regeneration.

Interestingly, a recent study has also shown that the disruption of mTOR function by rapamycin in neonatal mice leads to hearing loss [126]. Postnatal mice treated with rapamycin presented reduced ribbon synapse numbers and impaired exocytosis in ribbon synapses of inner hair cells. Adult mice at P28 treated with rapamycin presented normal cochlear morphology and hearing function [126]. These results indicate that mTOR signaling might also play an important role in the postnatal development and formation of cochlear hair cell synapses.

An inner ear specific conditional deletion of the phosphatase and tensin homolog (Pten), key modulator of PI3K, induced AKT hyperactivation and modulated the activation of GSK3 $\beta$ during the embryonal stage [127]. These Pten deficient mice presented neuronal abnormalities and additional rows of cochlear hair cells [127]. Therefore, PTEN/PI3K-AKT signaling might also be involved in inner ear development.

mTOR signaling regulates many essential cell processes; while mTORC1 regulates cell growth and metabolism, mTORC2 controls cell survival and cytoskeletal rearrangement. Recent studies indicate the involvement of mTOR signaling in auditory sensory hair cell regeneration, however, the precise mechanisms remain unknown (Figure 2). The reactivation time point of mTOR-dependent and mTOR-independent proteins seems to be critical for the development of sensory cells in the inner ear and maintenance of their regenerative capacities. Therefore, modulating tissue-specific mTOR, albeit a challenge, might also be an interesting target for regenerative medicine to treat hearing loss. 


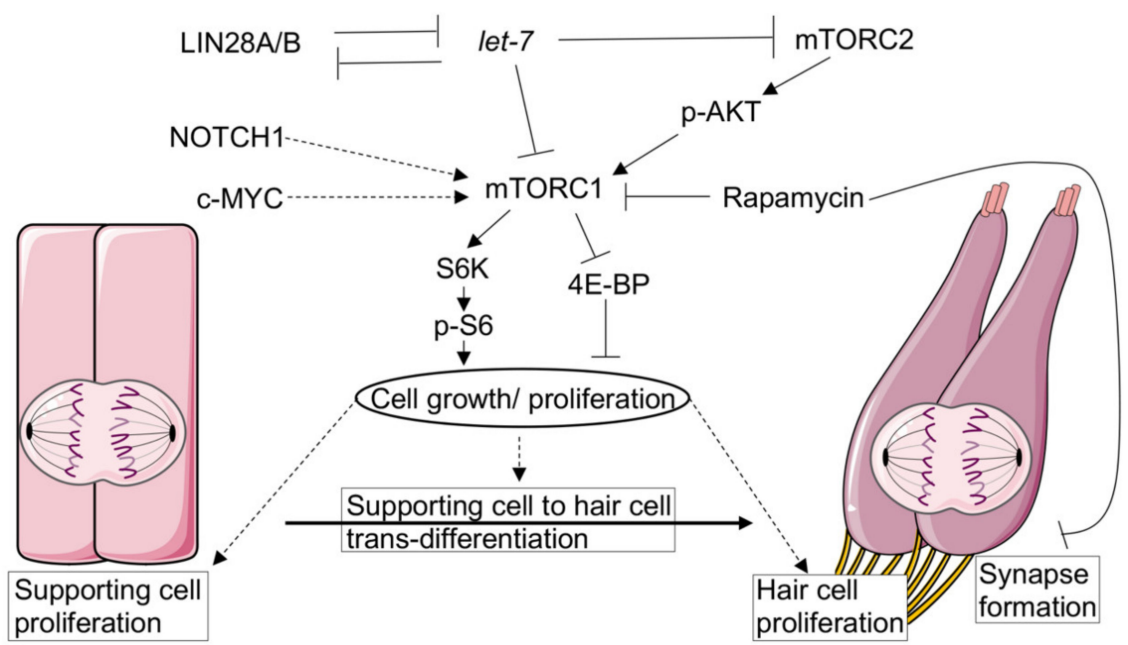

Figure 2. mTOR signaling in auditory sensory hair cell regeneration. mTORC1 is involved in supporting cell proliferation and hair cell (re)generation, effects that can be inhibited by rapamycin. Moreover, rapamycin inhibits inner hair cell synapse maturation at postnatal ages. mTORC2 might also be involved in hair cell generation, since p-AKT decreases when hair cell generation is lost but increases again when the regenerative capacity is regained. Dashed lines indicate unknown mechanisms. The figure was created with Servier Medical Art templates by Servier, which are licensed under a Creative Commons Attribution 3.0 Unported License; https:/ / smart.servier.com (accessed on 16 January 2021).

\section{4. mTOR Signaling in Auditory Sensory Hair Cell Survival and Death}

Prevention is the most effective strategy against hearing loss. Therefore, protecting and preserving sensible structures of the inner ear are crucial for hearing. Consequently, interventions to promote hair cell (and synapse) survival pathways or to inhibit hair cell death pathways are important therapeutic strategies. Oxidative damage is an important contributor to hearing loss. Thus, many antioxidants or stress/death signaling inhibitors have been tested to treat hearing loss in clinical trials $[3,128]$. However, none have made a breakthrough to date for the treatment of hearing loss and established in the clinic.

The protective role of rapamycin against damage to the inner ear has already been shown in numerous in vitro and in vivo studies. Several in vivo studies have reported that rapamycin protected hair cells and hearing function against the ototoxic effects of the chemotherapeutic agent cisplatin [129], the aminoglycoside antibiotic gentamicin [130], or against noise-induced hearing loss [131]. Moreover, rapamycin has been shown to protect against age-related hearing loss [132,133] and age-related outer hair cell loss [134]. Rapamycin has not only protective effects against hair cell damage [135], but also against the degeneration of the spiral ganglion (neurons innervating the sensory hair cells) [136] caused by aminoglycoside antibiotics in vitro. A further study using the rapamycin analog temsirolimus has also shown protection against spiral ganglion neuron degeneration in vivo [137]. In line with the protective effects of rapamycin, mTORC1 signaling has shown to be activated after damage to the cochlea: the activation of S6K and/or its downstream target $\mathrm{S} 6$ has been shown after damaging the cochlear sensory epithelium with gentamicin [138,139] or with cisplatin [140] and in the cochlea of aged mice [132]. Further supporting evidence that mTORC1 overactivation is involved in hair cell damaging events in the inner ear comes from a study where the conditional deletion of Raptor in the neurosensory epithelium protected mice against age-related hearing loss, both by preventing hair cell and synapse loss [132]. Conversely, Tsc1 conditional deletion in the neurosensory epithelium was accompanied by a sustained activation of mTORC1 and resulted in an early onset age-related hearing loss-while rapamycin treatment ameliorated this effect [132]. The authors used a Atoh1-Cre mouse for the conditional deletion of Raptor and Tsc1, which leads to Cre-mediated recombination in the cochlea as early as on 
embryonic day 14.5 (in addition to further regions such as the hindbrain, spinal cord and intestine) [141]. At this embryonic stage, hair cells are beginning to differentiate in the cochlea [141]. Despite this early induction of the knock-out, the authors did not observe any developmental defects in both Raptor or Tsc1 conditional knock-out mice [132]. The authors did also not find an upregulation of p-AKT Ser473 after the conditional deletion of Raptor [132], an effect commonly seen due to the negative feedback of mTORC1 towards IRS-PI3K-AKT (see Section 2.3).

Oxidative stress is known to modulate mTORC1 signaling [49]. The Tsc1 conditional knock-out mice had elevated ROS markers and a disbalance of pro-oxidant/antioxidant gene expression levels [132]. Treatment with the antioxidant N-acetylcysteine (NAC) strongly lowered p-S6 levels and rescued hair cell loss [132]. This suggests that elevated ROS levels and oxidative stress are hair cell-damaging events in Tsc1 knock-out mice. Mitochondria are known as important sources of ROS, however, results from transmission electron microscopy (TEM) indicated no mitochondrial defects in hair cells of Tsc1 conditional knock-out mice. In contrast, the authors detected abnormal peroxisomes by TEM in hair cells and observed TSC1 in peroxisomes of hair cells [132]. Based on these findings, the authors suggested the peroxisome as a principal source of ROS and as regulating organelle of mTORC1 signaling in the auditory hair cells [132].

An important downstream event of mTORC1 is the regulation and inhibition of autophagy (see Section 2.1). The importance of autophagy in the development of the cochlea and in different hearing loss models has been recognized (reviewed in [142], see [126]). Fu et al. showed that, after exposure with the aminoglycoside neomycin, Tsc1 conditional knock-out mice had much less GFP-LC3 puncta and no autophagosomes compared to control mice. Therefore, autophagy was impaired in Tsc1 knock-out mice [132]. Mice deficient in Atg5 in hair cells showed a normal development of hair cells, however, with rapid postnatal degeneration of the hair cells and profound hearing loss already occurring at hearing onset (P14) [143]. Mice with a conditional deletion of Atg7 specifically in outer hair cells also showed profound hearing loss, due to damage to the stereocilia, the degeneration of outer hair cell afferent synapses and eventually outer hair cell loss. Loss of Atg7 implicated impaired autophagy and dysfunction of mitochondria, leading to the accumulation of damaged mitochondria [144]. Moreover, impaired autophagy correlated with both noise-induced hearing loss [131] and aminoglycoside-induced hair cell loss severity [135]. Induction of autophagy protected against hair cell loss in both studies, whereas the inhibition of autophagy increased hair cell loss leading to hearing loss $[131,135]$.

AMPK, which interacts in multiple manners with mTOR [12], has also been shown to modulate hearing loss. A study reported that treatment with the AMPK activator AICAR increases PGC- $1 \alpha$ mRNA levels and that mice treated with AICAR recover faster from noise insults [145]. Ampk $\alpha 1$ knock-out mice and wildtype mice had similar hearing thresholds before and directly after noise exposure [146]. However, seven days after noise exposure, Ampk 1 knock-out mice had significantly higher thresholds than wild-type mice [146]. These results indicate disrupted recovery from noise-insult due to Ampk loss. The authors showed that this effect was at least in part due to the reduced expression of BK channels, suggesting that AMPK might stimulate BK channels and prevent noiseinduced Ca2+-overload [146]. In contrast, it has also been shown that noise-activated AMPK $\alpha$ by phosphorylating AMPK $\alpha$ at Thr172, and that phosphorylation levels augment with increasing noise levels [147]. The knock-down of Ampk $\alpha 1$ or its activating liver kinase B1 (Lkb1) by siRNA or pharmacological inhibition with Compound C protected the mice against noise-induced hearing loss, and preserved hair cells and synaptic ribbons from degeneration [147]. Interestingly, reducing the AMPK $\alpha 1$ activity rescued premature hearing loss in a mouse model of mitochondrial deafness [148]. These mice showed significantly less cell death, synapse and spiral ganglion neuron loss [149]. Single heterozygous Ampk 1 knock-out mice also completely recovered their hearing thresholds from a noise insult from which the wild-type mice only partly recovered [149]. These results reveal 
a contradictory role of AMPK in hearing loss. Given that AMPK inhibits mTORC1 (see Section 2.1 and [12]), and that it phosphorylates ULK1 at different sites to promote autophagy $[70,150,151]$, we would expect a protective effect on hearing loss. Although the reason for these conflicting results is not clear, we can note that the complete deletion of Ampk 1 has deleterious effects [146], whereas partial inhibition by siRNA [147] or heterozygous knock-out $[148,149]$ has protective effects on hearing loss. AMPK might be protective, but the increasing levels after noise exposure can tip the balance towards hair cell loss [147]. Moreover, it is important to note that there was no difference in ULK1 phosphorylation on the AMPK-dependent site Ser555 between wild-type mice and Ampk 1 heterozygous knock-out mice [149]. Phosphorylation of mTOR on Ser2448 (AKT and/or S6K depend site of unknown significance, see [152]) was also unchanged between wild-type mice and Ampk 1 heterozygous knock-out mice [149]. These results suggest that deleterious effects mediated by AMPK are independent of autophagy and mTOR.

The antidiabetic drug metformin has also been shown to inhibit mTORC1 signaling, via mechanisms dependent on AMPK and the TSC at lower doses and AMPK/TSC independent mechanisms at higher doses [153]. In the inner ear, metformin has shown protective properties. It protected against gentamicin [154] and cisplatin $[155,156]$ ototoxicity in an auditory cell line and against gentamicin-induced hair cell death in cochlear explants in vitro $[157,158]$. Metformin was also otoprotective in vivo against noise-induced hearing loss [159], cisplatin-induced hearing loss [156], pneumococcal meningitis-induced hearing loss [160], but not against gentamicin-induced hearing loss in guinea pigs [158].

Interestingly, in a model of Pendred syndrome, a syndromic form of hereditary hearing loss, cochlear epithelial cells derived from patient-derived induced pluripotent stem cells showed that both rapamycin and metformin are protective against cell death [161]. In a follow-up study, the authors defined a low-dose rapamycin treatment for Pendred syndrome [162] which is now being investigated in a clinical trial [163].

SESTRIN-2 is one of the upstream modulators of mTORC1 and can exert its function via AMPK during energy sensing and via the inhibition of GATOR2 during amino-acid sensing [164]. SESTRIN-2 as a leucine sensor inhibits mTORC1 activation when leucine levels are low [40] (see Section 2.1). The roles of Sestrins in the inner ear have only recently started to be elucidated. Sestrin-2 is expressed in hair cells, supporting cells and the spiral ganglion neuron in the cochlea $[138,165]$. SESTRIN-2 levels in the cochlea are both reduced in aged-mice or after damage with gentamicin [138,165]. Notably, the ablation of Sestrin-2 enhanced both age-related hearing loss [165] and gentamicin-induced hair cell loss [138]. A potential role of mTORC1 overactivation in the increased susceptibility of Sestrin-2 knockout mice to ototoxic damage of hair cells has been discussed [166]. In addition to regulating mTORC1, Sestrins are implicated in different cellular processes and are considered to be essential components of the antioxidant defense mechanism.

In contrast to mTORC1 signaling, the role of $\mathrm{mTORC} 2$ in the inner ear remains unknown to date (Figure 3). Nevertheless, there is important evidence that the mTORC2 regulating PI3K-AKT pathway is associated with hair cell protection in the inner ear. Early studies using aminoglycosides found that mice treated with kanamycin for seven days showed a downregulation of PI3K-AKT signaling in hair cells [167]. Neonatal rat cochlear explants exposed to PI3K or AKT inhibitors together with gentamicin exhibited increased hair cell damage in comparison to gentamicin alone [168]. Similarly, AKT signaling was reduced in the hair cells of aged mice [169]. Interestingly, mice exposed to mild noise-insults fully recovered their hearing with no change of p-AKT Ser473 in hair cells, whereas detrimental noise-insults led to permanent hearing loss and the concomitant downregulation of p-AKT Ser473 in hair cells [170]. This study also showed that knock-down of the regulatory PI3K subunit $\mathrm{p} 85 \alpha$ reduced $\mathrm{p}$-AKT Ser473 levels and led to permanent hearing loss after mild noise-insults, while control mice fully recovered [170]. Moreover, Akt1-knockout mice recovered less fast from mild noise-insults than wild-type mice [170]. These results indicate that PI3K-AKT signaling confers protection against damage to the inner ear and is essential for hair cell survival. Another study used immortalized multipotent otic progenitor 
cells cultured in suspension (otospheres) and investigated signaling pathways involved in proliferation versus differentiation to identify the mechanisms involved in hair cell survival [171]. They used an unbiased RNA-seq approach to investigate the transcriptome of proliferating versus differentiating otospheres, and found that the PI3K-AKT and mTOR pathway were top pathways of differentially expressed genes [171]. For their subsequent analyses, the authors focused on PI3K signaling. After the pharmacological inhibition or conditional deletion of Pten (which antagonizes PI3K activation), the authors showed increased hair cell survival after gentamicin-induced damage in cochlear explants [171]. In addition, AKT has shown to be important for normal hearing, since $A k t 1$ and $A k t 2 / 3$ double knock-out mice showed elevated hearing thresholds [172]. IGF-1, which activates PI3K-AKT signaling via its receptor (see Section 2.1), has shown to be important in both development and cochlear protection (reviewed in [173] and [174]). IGF-1 was protective in animal models of noise-induced hearing loss [175] and aminoglycoside-induced hair cell loss [176]. Recently, IGF-1 also showed involvement in the preservation of cochlear ribbon synapses [177]. Moreover, different IGF1 gene mutations in humans are associated with hearing loss [174]. The therapeutic effect of IGF-1 in humans has also been investigated in a randomized controlled clinical trial in patients with sudden sensorineural hearing loss refractory to systemic corticosteroid treatment (compared to intratympanic dexamethasone injections). Although there was no difference in the primary outcome (hearing improvement in pure-tone audiometry average hearing thresholds 8 weeks after treatment), there was a significant improvement in the IGF-1-treated group in pure-tone average hearing thresholds occurring over time [178]. Based on all these results, the question arises whether mTORC2 signaling could exert a protective role in the inner ear (Figure 3).

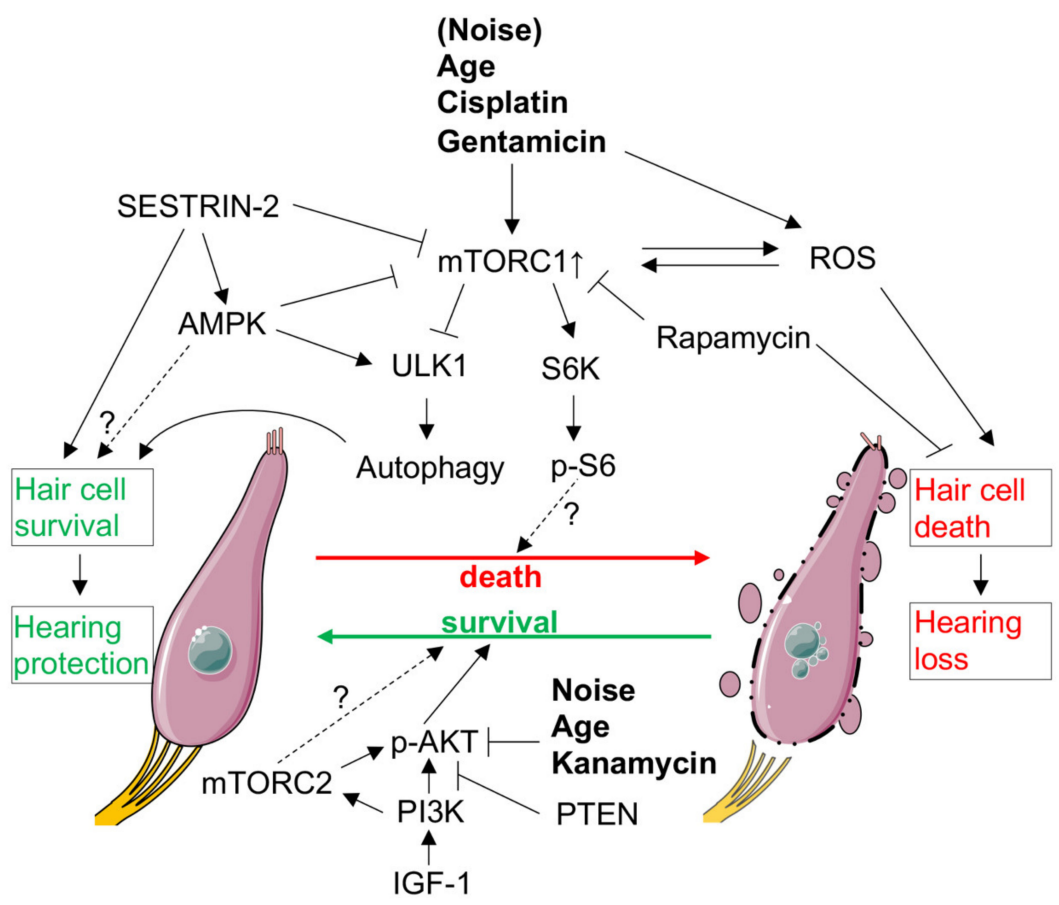

Figure 3. mTOR signaling in auditory sensory hair cell survival and death. mTORC1 is activated after damage due to age or ototoxic drugs which leads to hair cell death as well as damage to the spiral ganglion neurons/synapses. Rapamycin protects against these damaging insults by preserving the hair cells and related neural structures. The downstream damaging effects of mTORC1 overactivation are not well known. These might be due to ROS and the inhibition of autophagy. Although PI3KAKT signaling protects against hair cell death, the role of mTORC2 remains unknown. Dashed lines indicate unknown mechanisms or effects. The figure was created with Servier Medical Art templates by Servier, which are licensed under a Creative Commons Attribution 3.0 Unported License; https:/ / smart.servier.com (accessed on 16 January 2021). 


\section{Open Questions}

Despite recent advancements in the understanding of mTOR signaling in the inner ear, there are many open questions that remain. The most advanced study that investigated the role of mTORC1 in hearing loss is the study performed by Fu et. al. [132]. They generated mouse models with deletions of Raptor and Tsc1 in hair cells and supporting cells [132]. Due to the little amount of hair cells in the inner ear, many studies investigate the entire sensory epithelium (hair cells together with supporting cells) instead of specific cell types. An important question that needs to be addressed is the cell specificity of mTORC1 role in the inner ear: is mTORC1 deleterious in the hair cells, or is overactivation of mTORC1 in the supporting cells important for the damaging effects? What is the role of mTORC1 in the spiral ganglion neurons? Different cell types might have divergent mTOR effects. Moreover, to understand what makes mTORC1 overactivation a damaging event in hair cells will need to scrutinize the downstream mechanisms. Production of high levels of ROS and the inhibition of autophagy are common mechanisms in ototoxicity and modulated by mTORC1. Further investigations to clarify the oxidative function of mTORC1 in the inner ear compartments are required. The interplay between upstream modulators such as Sestrins and AMPK with mTORC1 will also need further investigation in the inner ear.

The role of mTORC2 in the inner ear is unknown. Rapamycin is known to be a mTORC1-specific inhibitor, but prolonged rapamycin treatment has also been shown to inhibit mTORC2 [75]. Rapamycin was protective against hair cell and hearing loss in numerous studies, even over a prolonged period of time. Therefore, potential effects on mTORC2 also need to be considered. Although much evidence points to a protective role on hair cells from the PI3K-AKT pathway, the direct involvement of mTORC2 remains to be demonstrated.

In addition to investigating to the role of mTOR under pathological conditions (age, noise, ototoxic agents, etc.), it will also be interesting to investigate the physiological role of mTOR in the individual cells of the inner ear. Such studies might include the investigation of cell type-specific mTORC1 or mTORC2 knock-out models.

As reviewed earlier, mTORC1 seems to play a role in auditory hair cell regeneration, while the role of mTORC2 in regeneration is less clear (see Section 3). How does mTOR interact with other signaling pathways? Is mTOR activation sufficient for hair cell regeneration? Which are the other mTOR-independent factors? Answers to these questions might open new therapeutic strategies to regenerate hair cells. Given the simultaneous role of mTORC1 in both auditory hair cell regeneration and the promotion of hair cell death, potential interventions must balance the beneficial effects of the former against the detrimental effects of the latter. In order to achieve this, future studies will need to precisely decipher the role of $\mathrm{mTOR}$ signaling in the inner ear.

\section{Conclusions and Future Perspectives}

Understanding mTOR signaling in the inner ear has only recently started to emerge. It has been shown that mTOR is involved in regenerative processes by promoting the proliferation and trans-differentiation of supporting cells into hair cells. Moreover, mTOR signaling is involved in auditory hair cell death and survival mechanisms. Therefore, advanced examination of this pathway could help to develop effective therapeutic strategies to prevent hearing loss and restore lost hair cells. Discrimination between the negative role of mTORC1 in hair cell survival and the positive role in hair cell regeneration will allow precise fine-tuning of potential therapeutic approaches. As reviewed earlier, mTORC2 might have a protective role and promote hair cell survival. However, future studies will need to dissect the precise roles of mTOR signaling in the inner ear. We posit that mTOR signaling has therapeutic potential to treat hearing loss. 
Author Contributions: Conceptualization, M.C. and S.L.; resources, D.B.; writing-original draft preparation, M.C. and S.L.; writing-review and editing, S.L. and D.B.; supervision, S.L. and D.B.; funding acquisition, M.C. All authors have read and agreed to the published version of the manuscript.

Funding: This research was funded by the Swiss National Science Foundation (SNSF) with a national MD-PhD scholarship (323530_191222) to M.C.

Conflicts of Interest: The authors declare no conflict of interest. The funders had no role in the design of the study; in the collection, analyses, or interpretation of data; in the writing of the manuscript, or in the decision to publish the results.

\section{References}

1. WHO. Global Estimates on Prevalence of Hearing Loss. Available online: https://www.who.int/pbd/deafness/estimates/en/ (accessed on 16 February 2021).

2. Geleoc, G.S.; Holt, J.R. Sound strategies for hearing restoration. Science 2014, 344, 1241062. [CrossRef]

3. Wang, J.; Puel, J.L. Toward Cochlear Therapies. Physiol. Rev. 2018, 98, 2477-2522. [CrossRef] [PubMed]

4. Wang, J.; Puel, J.L. Presbycusis: An Update on Cochlear Mechanisms and Therapies. J. Clin. Med. 2020, 9, 218. [CrossRef] [PubMed]

5. Saxton, R.A.; Sabatini, D.M. mTOR Signaling in Growth, Metabolism, and Disease. Cell 2017, 169, 361-371. [CrossRef] [PubMed]

6. Dazert, E.; Hall, M.N. mTOR signaling in disease. Curr. Opin. Cell Biol. 2011, 23, 744-755. [CrossRef] [PubMed]

7. Heitman, J.; Movva, N.R.; Hall, M.N. Targets for cell cycle arrest by the immunosuppressant rapamycin in yeast. Science 1991, 253, 905-909. [CrossRef] [PubMed]

8. Harrison, D.E.; Strong, R.; Sharp, Z.D.; Nelson, J.F.; Astle, C.M.; Flurkey, K.; Nadon, N.L.; Wilkinson, J.E.; Frenkel, K.; Carter, C.S.; et al. Rapamycin fed late in life extends lifespan in genetically heterogeneous mice. Nature 2009, 460, 392-395. [CrossRef] [PubMed]

9. Johnson, S.C.; Rabinovitch, P.S.; Kaeberlein, M. mTOR is a key modulator of ageing and age-related disease. Nature 2013, 493, 338-345. [CrossRef]

10. Liu, G.Y.; Sabatini, D.M. mTOR at the nexus of nutrition, growth, ageing and disease. Nat. Rev. Mol. Cell Biol. 2020, 21, 183-203. [CrossRef]

11. Fu, W.; Hall, M.N. Regulation of mTORC2 Signaling. Genes 2020, 11, 1045. [CrossRef]

12. Gonzalez, A.; Hall, M.N.; Lin, S.C.; Hardie, D.G. AMPK and TOR: The Yin and Yang of Cellular Nutrient Sensing and Growth Control. Cell Metab. 2020, 31, 472-492. [CrossRef]

13. Aylett, C.H.; Sauer, E.; Imseng, S.; Boehringer, D.; Hall, M.N.; Ban, N.; Maier, T. Architecture of human mTOR complex 1. Science 2016, 351, 48-52. [CrossRef]

14. Kim, D.H.; Sarbassov, D.D.; Ali, S.M.; Latek, R.R.; Guntur, K.V.; Erdjument-Bromage, H.; Tempst, P.; Sabatini, D.M. GbetaL, a positive regulator of the rapamycin-sensitive pathway required for the nutrient-sensitive interaction between raptor and $\mathrm{mTOR}$. Mol. Cell 2003, 11, 895-904. [CrossRef]

15. Loewith, R.; Jacinto, E.; Wullschleger, S.; Lorberg, A.; Crespo, J.L.; Bonenfant, D.; Oppliger, W.; Jenoe, P.; Hall, M.N. Two TOR complexes, only one of which is rapamycin sensitive, have distinct roles in cell growth control. Mol. Cell 2002, 10, 457-468. [CrossRef]

16. Kim, D.H.; Sarbassov, D.D.; Ali, S.M.; King, J.E.; Latek, R.R.; Erdjument-Bromage, H.; Tempst, P.; Sabatini, D.M. mTOR interacts with raptor to form a nutrient-sensitive complex that signals to the cell growth machinery. Cell 2002, 110, 163-175. [CrossRef]

17. Bierer, B.E.; Mattila, P.S.; Standaert, R.F.; Herzenberg, L.A.; Burakoff, S.J.; Crabtree, G.; Schreiber, S.L. Two distinct signal transmission pathways in T lymphocytes are inhibited by complexes formed between an immunophilin and either FK506 or rapamycin. Proc. Natl. Acad. Sci. USA 1990, 87, 9231-9235. [CrossRef]

18. Benjamin, D.; Colombi, M.; Moroni, C.; Hall, M.N. Rapamycin passes the torch: A new generation of mTOR inhibitors. Nat. Rev. Drug Discov. 2011, 10, 868-880. [CrossRef]

19. Schalm, S.S.; Blenis, J. Identification of a conserved motif required for mTOR signaling. Curr. Biol. 2002, 12, 632-639. [CrossRef]

20. Schalm, S.S.; Fingar, D.C.; Sabatini, D.M.; Blenis, J. TOS motif-mediated raptor binding regulates 4E-BP1 multisite phosphorylation and function. Curr. Biol. 2003, 13, 797-806. [CrossRef]

21. Dibble, C.C.; Cantley, L.C. Regulation of mTORC1 by PI3K signaling. Trends Cell Biol. 2015, 25, 545-555. [CrossRef]

22. Manning, B.D.; Toker, A. AKT/PKB Signaling: Navigating the Network. Cell 2017, 169, 381-405. [CrossRef] [PubMed]

23. Inoki, K.; Li, Y.; Zhu, T.; Wu, J.; Guan, K.L. TSC2 is phosphorylated and inhibited by Akt and suppresses mTOR signalling. Nat. Cell Biol. 2002, 4, 648-657. [CrossRef] [PubMed]

24. Manning, B.D.; Tee, A.R.; Logsdon, M.N.; Blenis, J.; Cantley, L.C. Identification of the tuberous sclerosis complex-2 tumor suppressor gene product tuberin as a target of the phosphoinositide 3-kinase/akt pathway. Mol. Cell 2002, 10, 151-162. [CrossRef]

25. Potter, C.J.; Pedraza, L.G.; Xu, T. Akt regulates growth by directly phosphorylating Tsc2. Nat. Cell Biol. 2002, 4, 658-665. [CrossRef]

26. Dibble, C.C.; Elis, W.; Menon, S.; Qin, W.; Klekota, J.; Asara, J.M.; Finan, P.M.; Kwiatkowski, D.J.; Murphy, L.O.; Manning, B.D. TBC1D7 is a third subunit of the TSC1-TSC2 complex upstream of mTORC1. Mol. Cell 2012, 47, 535-546. [CrossRef] 
27. Menon, S.; Dibble, C.C.; Talbott, G.; Hoxhaj, G.; Valvezan, A.J.; Takahashi, H.; Cantley, L.C.; Manning, B.D. Spatial control of the TSC complex integrates insulin and nutrient regulation of mTORC1 at the lysosome. Cell 2014, 156, 771-785. [CrossRef]

28. Inoki, K.; Li, Y.; Xu, T.; Guan, K.L. Rheb GTPase is a direct target of TSC2 GAP activity and regulates mTOR signaling. Genes Dev. 2003, 17, 1829-1834. [CrossRef]

29. Long, X.; Lin, Y.; Ortiz-Vega, S.; Yonezawa, K.; Avruch, J. Rheb binds and regulates the mTOR kinase. Curr. Biol. 2005, 15, 702-713. [CrossRef]

30. Saito, K.; Araki, Y.; Kontani, K.; Nishina, H.; Katada, T. Novel role of the small GTPase Rheb: Its implication in endocytic pathway independent of the activation of mammalian target of rapamycin. J. Biochem. 2005, 137, 423-430. [CrossRef]

31. Sancak, Y.; Peterson, T.R.; Shaul, Y.D.; Lindquist, R.A.; Thoreen, C.C.; Bar-Peled, L.; Sabatini, D.M. The Rag GTPases bind raptor and mediate amino acid signaling to mTORC1. Science 2008, 320, 1496-1501. [CrossRef]

32. Kim, E.; Goraksha-Hicks, P.; Li, L.; Neufeld, T.P.; Guan, K.L. Regulation of TORC1 by Rag GTPases in nutrient response. Nat. Cell Biol. 2008, 10, 935-945. [CrossRef]

33. Sancak, Y.; Bar-Peled, L.; Zoncu, R.; Markhard, A.L.; Nada, S.; Sabatini, D.M. Ragulator-Rag complex targets mTORC1 to the lysosomal surface and is necessary for its activation by amino acids. Cell 2010, 141, 290-303. [CrossRef]

34. Gonzalez, A.; Hall, M.N. Nutrient sensing and TOR signaling in yeast and mammals. EMBO J. 2017, 36, 397-408. [CrossRef]

35. Rogala, K.B.; Gu, X.; Kedir, J.F.; Abu-Remaileh, M.; Bianchi, L.F.; Bottino, A.M.S.; Dueholm, R.; Niehaus, A.; Overwijn, D.; Fils, A.P.; et al. Structural basis for the docking of mTORC1 on the lysosomal surface. Science 2019, 366, 468-475. [CrossRef]

36. Bar-Peled, L.; Chantranupong, L.; Cherniack, A.D.; Chen, W.W.; Ottina, K.A.; Grabiner, B.C.; Spear, E.D.; Carter, S.L.; Meyerson, M.; Sabatini, D.M. A Tumor suppressor complex with GAP activity for the Rag GTPases that signal amino acid sufficiency to mTORC1. Science 2013, 340, 1100-1106. [CrossRef]

37. Shen, K.; Huang, R.K.; Brignole, E.J.; Condon, K.J.; Valenstein, M.L.; Chantranupong, L.; Bomaliyamu, A.; Choe, A.; Hong, C.; $\mathrm{Yu}, \mathrm{Z}$; ; et al. Architecture of the human GATOR1 and GATOR1-Rag GTPases complexes. Nature 2018, 556, 64-69. [CrossRef]

38. Peng, M.; Yin, N.; Li, M.O. SZT2 dictates GATOR control of mTORC1 signalling. Nature 2017, 543, 433-437. [CrossRef]

39. Wolfson, R.L.; Chantranupong, L.; Wyant, G.A.; Gu, X.; Orozco, J.M.; Shen, K.; Condon, K.J.; Petri, S.; Kedir, J.; Scaria, S.M.; et al. KICSTOR recruits GATOR1 to the lysosome and is necessary for nutrients to regulate mTORC1. Nature 2017, 543, 438-442. [CrossRef]

40. Wolfson, R.L.; Chantranupong, L.; Saxton, R.A.; Shen, K.; Scaria, S.M.; Cantor, J.R.; Sabatini, D.M. Sestrin2 is a leucine sensor for the mTORC1 pathway. Science 2016, 351, 43-48. [CrossRef]

41. Chantranupong, L.; Scaria, S.M.; Saxton, R.A.; Gygi, M.P.; Shen, K.; Wyant, G.A.; Wang, T.; Harper, J.W.; Gygi, S.P.; Sabatini, D.M. The CASTOR Proteins Are Arginine Sensors for the mTORC1 Pathway. Cell 2016, 165, 153-164. [CrossRef]

42. Petit, C.S.; Roczniak-Ferguson, A.; Ferguson, S.M. Recruitment of folliculin to lysosomes supports the amino acid-dependent activation of Rag GTPases. J. Cell Biol. 2013, 202, 1107-1122. [CrossRef]

43. Tsun, Z.Y.; Bar-Peled, L.; Chantranupong, L.; Zoncu, R.; Wang, T.; Kim, C.; Spooner, E.; Sabatini, D.M. The folliculin tumor suppressor is a GAP for the RagC/D GTPases that signal amino acid levels to mTORC1. Mol. Cell 2013, 52, 495-505. [CrossRef]

44. Gu, X.; Orozco, J.M.; Saxton, R.A.; Condon, K.J.; Liu, G.Y.; Krawczyk, P.A.; Scaria, S.M.; Harper, J.W.; Gygi, S.P.; Sabatini, D.M. SAMTOR is an S-adenosylmethionine sensor for the mTORC1 pathway. Science 2017, 358, 813-818. [CrossRef]

45. Zoncu, R.; Bar-Peled, L.; Efeyan, A.; Wang, S.; Sancak, Y.; Sabatini, D.M. mTORC1 senses lysosomal amino acids through an inside-out mechanism that requires the vacuolar H(+)-ATPase. Science 2011, 334, 678-683. [CrossRef]

46. Rebsamen, M.; Pochini, L.; Stasyk, T.; de Araujo, M.E.; Galluccio, M.; Kandasamy, R.K.; Snijder, B.; Fauster, A.; Rudashevskaya, E.L.; Bruckner, M.; et al. SLC38A9 is a component of the lysosomal amino acid sensing machinery that controls mTORC1. Nature 2015, 519, 477-481. [CrossRef]

47. Reiling, J.H.; Sabatini, D.M. Stress and mTORture signaling. Oncogene 2006, 25, 6373-6383. [CrossRef]

48. Li, M.; Zhao, L.; Liu, J.; Liu, A.; Jia, C.; Ma, D.; Jiang, Y.; Bai, X. Multi-mechanisms are involved in reactive oxygen species regulation of mTORC1 signaling. Cell. Signal. 2010, 22, 1469-1476. [CrossRef] [PubMed]

49. Thedieck, K.; Holzwarth, B.; Prentzell, M.T.; Boehlke, C.; Klasener, K.; Ruf, S.; Sonntag, A.G.; Maerz, L.; Grellscheid, S.N.; Kremmer, E.; et al. Inhibition of mTORC1 by astrin and stress granules prevents apoptosis in cancer cells. Cell 2013, 154, 859-874. [CrossRef] [PubMed]

50. Dames, S.A.; Mulet, J.M.; Rathgeb-Szabo, K.; Hall, M.N.; Grzesiek, S. The solution structure of the FATC domain of the protein kinase target of rapamycin suggests a role for redox-dependent structural and cellular stability. J. Biol. Chem. 2005, 280, 20558-20564. [CrossRef] [PubMed]

51. Sarbassov, D.D.; Sabatini, D.M. Redox regulation of the nutrient-sensitive raptor-mTOR pathway and complex. J. Biol. Chem. 2005, 280, 39505-39509. [CrossRef] [PubMed]

52. Yoshida, S.; Hong, S.; Suzuki, T.; Nada, S.; Mannan, A.M.; Wang, J.; Okada, M.; Guan, K.L.; Inoki, K. Redox regulates mammalian target of rapamycin complex 1 (mTORC1) activity by modulating the TSC1/TSC2-Rheb GTPase pathway. J. Biol. Chem. 2011, 286, 32651-32660. [CrossRef]

53. Shimobayashi, M.; Hall, M.N. Making new contacts: The mTOR network in metabolism and signalling crosstalk. Nat. Rev. Mol. Cell Biol. 2014, 15, 155-162. [CrossRef] 
54. Settembre, C.; Zoncu, R.; Medina, D.L.; Vetrini, F.; Erdin, S.; Erdin, S.; Huynh, T.; Ferron, M.; Karsenty, G.; Vellard, M.C.; et al. A lysosome-to-nucleus signalling mechanism senses and regulates the lysosome via mTOR and TFEB. EMBO J. 2012, 31, 1095-1108. [CrossRef]

55. Roczniak-Ferguson, A.; Petit, C.S.; Froehlich, F.; Qian, S.; Ky, J.; Angarola, B.; Walther, T.C.; Ferguson, S.M. The transcription factor TFEB links mTORC1 signaling to transcriptional control of lysosome homeostasis. Sci. Signal. 2012, 5, ra42. [CrossRef]

56. Martina, J.A.; Chen, Y.; Gucek, M.; Puertollano, R. MTORC1 functions as a transcriptional regulator of autophagy by preventing nuclear transport of TFEB. Autophagy 2012, 8, 903-914. [CrossRef]

57. Ben-Sahra, I.; Hoxhaj, G.; Ricoult, S.J.H.; Asara, J.M.; Manning, B.D. mTORC1 induces purine synthesis through control of the mitochondrial tetrahydrofolate cycle. Science 2016, 351, 728-733. [CrossRef]

58. Duvel, K.; Yecies, J.L.; Menon, S.; Raman, P.; Lipovsky, A.I.; Souza, A.L.; Triantafellow, E.; Ma, Q.; Gorski, R.; Cleaver, S.; et al. Activation of a metabolic gene regulatory network downstream of mTOR complex 1. Mol. Cell 2010, 39, 171-183. [CrossRef]

59. Burnett, P.E.; Barrow, R.K.; Cohen, N.A.; Snyder, S.H.; Sabatini, D.M. RAFT1 phosphorylation of the translational regulators p70 S6 kinase and 4E-BP1. Proc. Natl. Acad. Sci. USA 1998, 95, 1432-1437. [CrossRef]

60. Hara, K.; Yonezawa, K.; Kozlowski, M.T.; Sugimoto, T.; Andrabi, K.; Weng, Q.P.; Kasuga, M.; Nishimoto, I.; Avruch, J. Regulation of eIF-4E BP1 phosphorylation by mTOR. J. Biol. Chem. 1997, 272, 26457-26463. [CrossRef]

61. Peterson, T.R.; Sengupta, S.S.; Harris, T.E.; Carmack, A.E.; Kang, S.A.; Balderas, E.; Guertin, D.A.; Madden, K.L.; Carpenter, A.E.; Finck, B.N.; et al. mTOR complex 1 regulates lipin 1 localization to control the SREBP pathway. Cell 2011, 146, 408-420. [CrossRef]

62. Ben-Sahra, I.; Howell, J.J.; Asara, J.M.; Manning, B.D. Stimulation of de novo pyrimidine synthesis by growth signaling through mTOR and S6K1. Science 2013, 339, 1323-1328. [CrossRef]

63. Robitaille, A.M.; Christen, S.; Shimobayashi, M.; Cornu, M.; Fava, L.L.; Moes, S.; Prescianotto-Baschong, C.; Sauer, U.; Jenoe, P.; Hall, M.N. Quantitative phosphoproteomics reveal mTORC1 activates de novo pyrimidine synthesis. Science 2013, 339, 1320-1323. [CrossRef]

64. Zid, B.M.; Rogers, A.N.; Katewa, S.D.; Vargas, M.A.; Kolipinski, M.C.; Lu, T.A.; Benzer, S.; Kapahi, P. 4E-BP extends lifespan upon dietary restriction by enhancing mitochondrial activity in Drosophila. Cell 2009, 139, 149-160. [CrossRef]

65. Morita, M.; Gravel, S.P.; Chenard, V.; Sikstrom, K.; Zheng, L.; Alain, T.; Gandin, V.; Avizonis, D.; Arguello, M.; Zakaria, C.; et al. mTORC1 controls mitochondrial activity and biogenesis through 4E-BP-dependent translational regulation. Cell Metab. 2013, 18, 698-711. [CrossRef]

66. Cunningham, J.T.; Rodgers, J.T.; Arlow, D.H.; Vazquez, F.; Mootha, V.K.; Puigserver, P. mTOR controls mitochondrial oxidative function through a YY1-PGC-1alpha transcriptional complex. Nature 2007, 450, 736-740. [CrossRef] [PubMed]

67. Hosokawa, N.; Hara, T.; Kaizuka, T.; Kishi, C.; Takamura, A.; Miura, Y.; Iemura, S.; Natsume, T.; Takehana, K.; Yamada, N.; et al. Nutrient-dependent mTORC1 association with the ULK1-Atg13-FIP200 complex required for autophagy. Mol. Biol. Cell 2009, 20, 1981-1991. [CrossRef]

68. Ganley, I.G.; Lam du, H.; Wang, J.; Ding, X.; Chen, S.; Jiang, X. ULK1.ATG13.FIP200 complex mediates mTOR signaling and is essential for autophagy. J. Biol. Chem. 2009, 284, 12297-12305. [CrossRef]

69. Jung, C.H.; Jun, C.B.; Ro, S.H.; Kim, Y.M.; Otto, N.M.; Cao, J.; Kundu, M.; Kim, D.H. ULK-Atg13-FIP200 complexes mediate mTOR signaling to the autophagy machinery. Mol. Biol. Cell 2009, 20, 1992-2003. [CrossRef]

70. Kim, J.; Kundu, M.; Viollet, B.; Guan, K.L. AMPK and mTOR regulate autophagy through direct phosphorylation of Ulk1. Nat. Cell Biol. 2011, 13, 132-141. [CrossRef]

71. Brown, E.J.; Albers, M.W.; Shin, T.B.; Ichikawa, K.; Keith, C.T.; Lane, W.S.; Schreiber, S.L. A mammalian protein targeted by G1-arresting rapamycin-receptor complex. Nature 1994, 369, 756-758. [CrossRef]

72. Sabatini, D.M.; Erdjument-Bromage, H.; Lui, M.; Tempst, P.; Snyder, S.H. RAFT1: A mammalian protein that binds to FKBP12 in a rapamycin-dependent fashion and is homologous to yeast TORs. Cell 1994, 78, 35-43. [CrossRef]

73. Sabers, C.J.; Martin, M.M.; Brunn, G.J.; Williams, J.M.; Dumont, F.J.; Wiederrecht, G.; Abraham, R.T. Isolation of a protein target of the FKBP12-rapamycin complex in mammalian cells. J. Biol. Chem. 1995, 270, 815-822. [CrossRef] [PubMed]

74. Jacinto, E.; Loewith, R.; Schmidt, A.; Lin, S.; Ruegg, M.A.; Hall, A.; Hall, M.N. Mammalian TOR complex 2 controls the actin cytoskeleton and is rapamycin insensitive. Nat. Cell Biol. 2004, 6, 1122-1128. [CrossRef]

75. Sarbassov, D.D.; Ali, S.M.; Sengupta, S.; Sheen, J.H.; Hsu, P.P.; Bagley, A.F.; Markhard, A.L.; Sabatini, D.M. Prolonged rapamycin treatment inhibits mTORC2 assembly and Akt/PKB. Mol. Cell 2006, 22, 159-168. [CrossRef]

76. Sarbassov, D.D.; Ali, S.M.; Kim, D.H.; Guertin, D.A.; Latek, R.R.; Erdjument-Bromage, H.; Tempst, P.; Sabatini, D.M. Rictor, a novel binding partner of $\mathrm{mTOR}$, defines a rapamycin-insensitive and raptor-independent pathway that regulates the cytoskeleton. Curr. Biol. 2004, 14, 1296-1302. [CrossRef]

77. Jacinto, E.; Facchinetti, V.; Liu, D.; Soto, N.; Wei, S.; Jung, S.Y.; Huang, Q.; Qin, J.; Su, B. SIN1/MIP1 maintains rictor-mTOR complex integrity and regulates Akt phosphorylation and substrate specificity. Cell 2006, 127, 125-137. [CrossRef]

78. Frias, M.A.; Thoreen, C.C.; Jaffe, J.D.; Schroder, W.; Sculley, T.; Carr, S.A.; Sabatini, D.M. mSin1 is necessary for Akt/PKB phosphorylation, and its isoforms define three distinct mTORC2s. Curr. Biol. 2006, 16, 1865-1870. [CrossRef]

79. Yang, Q.; Inoki, K.; Ikenoue, T.; Guan, K.L. Identification of Sin1 as an essential TORC2 component required for complex formation and kinase activity. Genes Dev. 2006, 20, 2820-2832. [CrossRef]

80. Stuttfeld, E.; Aylett, C.H.; Imseng, S.; Boehringer, D.; Scaiola, A.; Sauer, E.; Hall, M.N.; Maier, T.; Ban, N. Architecture of the human mTORC2 core complex. eLife 2018, 7, e33101. [CrossRef] 
81. Chen, X.; Liu, M.; Tian, Y.; Li, J.; Qi, Y.; Zhao, D.; Wu, Z.; Huang, M.; Wong, C.C.L.; Wang, H.W.; et al. Cryo-EM structure of human mTOR complex 2. Cell Res. 2018, 28, 518-528. [CrossRef]

82. Scaiola, A.; Mangia, F.; Imseng, S.; Boehringer, D.; Berneiser, K.; Shimobayashi, M.; Stuttfeld, E.; Hall, M.N.; Ban, N.; Maier, T. The 3.2-A resolution structure of human mTORC2. Sci. Adv. 2020, 6, eabc1251. [CrossRef] [PubMed]

83. Liu, P.; Gan, W.; Chin, Y.R.; Ogura, K.; Guo, J.; Zhang, J.; Wang, B.; Blenis, J.; Cantley, L.C.; Toker, A.; et al. PtdIns(3,4,5)P3Dependent Activation of the mTORC2 Kinase Complex. Cancer Discov. 2015, 5, 1194-1209. [CrossRef] [PubMed]

84. Gan, X.; Wang, J.; Su, B.; Wu, D. Evidence for direct activation of mTORC2 kinase activity by phosphatidylinositol 3,4,5trisphosphate. J. Biol. Chem. 2011, 286, 10998-11002. [CrossRef] [PubMed]

85. Kovalski, J.R.; Bhaduri, A.; Zehnder, A.M.; Neela, P.H.; Che, Y.; Wozniak, G.G.; Khavari, P.A. The Functional Proximal Proteome of Oncogenic Ras Includes mTORC2. Mol. Cell 2019, 73, 830-844.e812. [CrossRef]

86. Tumaneng, K.; Schlegelmilch, K.; Russell, R.C.; Yimlamai, D.; Basnet, H.; Mahadevan, N.; Fitamant, J.; Bardeesy, N.; Camargo, F.D.; Guan, K.L. YAP mediates crosstalk between the Hippo and PI(3)K-TOR pathways by suppressing PTEN via miR-29. Nat. Cell Biol. 2012, 14, 1322-1329. [CrossRef]

87. Esen, E.; Chen, J.; Karner, C.M.; Okunade, A.L.; Patterson, B.W.; Long, F. WNT-LRP5 signaling induces Warburg effect through mTORC2 activation during osteoblast differentiation. Cell Metab. 2013, 17, 745-755. [CrossRef]

88. Daulat, A.M.; Bertucci, F.; Audebert, S.; Serge, A.; Finetti, P.; Josselin, E.; Castellano, R.; Birnbaum, D.; Angers, S.; Borg, J.P. PRICKLE1 Contributes to Cancer Cell Dissemination through Its Interaction with mTORC2. Dev. Cell 2016, 37, 311-325. [CrossRef]

89. Kazyken, D.; Magnuson, B.; Bodur, C.; Acosta-Jaquez, H.A.; Zhang, D.; Tong, X.; Barnes, T.M.; Steinl, G.K.; Patterson, N.E.; Altheim, C.H.; et al. AMPK directly activates mTORC2 to promote cell survival during acute energetic stress. Sci. Signal. 2019, 12, eaav3249. [CrossRef]

90. Betz, C.; Hall, M.N. Where is mTOR and what is it doing there? J. Cell Biol. 2013, 203, 563-574. [CrossRef]

91. Pearce, L.R.; Komander, D.; Alessi, D.R. The nuts and bolts of AGC protein kinases. Nat. Rev. Mol. Cell Biol. 2010, 11, 9-22. [CrossRef]

92. Sarbassov, D.D.; Guertin, D.A.; Ali, S.M.; Sabatini, D.M. Phosphorylation and regulation of Akt/PKB by the rictor-mTOR complex. Science 2005, 307, 1098-1101. [CrossRef]

93. Hresko, R.C.; Mueckler, M. mTOR.RICTOR is the Ser473 kinase for Akt/protein kinase B in 3T3-L1 adipocytes. J. Biol. Chem. 2005, 280, 40406-40416. [CrossRef]

94. Oh, W.J.; Wu, C.C.; Kim, S.J.; Facchinetti, V.; Julien, L.A.; Finlan, M.; Roux, P.P.; Su, B.; Jacinto, E. mTORC2 can associate with ribosomes to promote cotranslational phosphorylation and stability of nascent Akt polypeptide. EMBO J. 2010, 29, 3939-3951. [CrossRef]

95. Garcia-Martinez, J.M.; Alessi, D.R. mTOR complex 2 (mTORC2) controls hydrophobic motif phosphorylation and activation of serum- and glucocorticoid-induced protein kinase 1 (SGK1). Biochem. J. 2008, 416, 375-385. [CrossRef]

96. Gu, Y.; Albuquerque, C.P.; Braas, D.; Zhang, W.; Villa, G.R.; Bi, J.; Ikegami, S.; Masui, K.; Gini, B.; Yang, H.; et al. mTORC2 Regulates Amino Acid Metabolism in Cancer by Phosphorylation of the Cystine-Glutamate Antiporter xCT. Mol. Cell 2017, 67, 128-138. [CrossRef]

97. Shah, O.J.; Wang, Z.; Hunter, T. Inappropriate activation of the TSC/Rheb/mTOR/S6K cassette induces IRS1/2 depletion, insulin resistance, and cell survival deficiencies. Curr. Biol. 2004, 14, 1650-1656. [CrossRef]

98. Harrington, L.S.; Findlay, G.M.; Gray, A.; Tolkacheva, T.; Wigfield, S.; Rebholz, H.; Barnett, J.; Leslie, N.R.; Cheng, S.; Shepherd, P.R.; et al. The TSC1-2 tumor suppressor controls insulin-PI3K signaling via regulation of IRS proteins. J. Cell Biol. 2004, 166, 213-223. [CrossRef]

99. Um, S.H.; Frigerio, F.; Watanabe, M.; Picard, F.; Joaquin, M.; Sticker, M.; Fumagalli, S.; Allegrini, P.R.; Kozma, S.C.; Auwerx, J.; et al. Absence of S6K1 protects against age- and diet-induced obesity while enhancing insulin sensitivity. Nature 2004, 431, 200-205. [CrossRef]

100. Yu, Y.; Yoon, S.O.; Poulogiannis, G.; Yang, Q.; Ma, X.M.; Villen, J.; Kubica, N.; Hoffman, G.R.; Cantley, L.C.; Gygi, S.P.; et al. Phosphoproteomic analysis identifies Grb10 as an mTORC1 substrate that negatively regulates insulin signaling. Science 2011, 332, 1322-1326. [CrossRef]

101. Hsu, P.P.; Kang, S.A.; Rameseder, J.; Zhang, Y.; Ottina, K.A.; Lim, D.; Peterson, T.R.; Choi, Y.; Gray, N.S.; Yaffe, M.B.; et al. The mTOR-regulated phosphoproteome reveals a mechanism of mTORC1-mediated inhibition of growth factor signaling. Science 2011, 332, 1317-1322. [CrossRef]

102. Lim, M.A.; Riedel, H.; Liu, F. Grb10: More than a simple adaptor protein. Front. Biosci. 2004, 9, 387-403. [CrossRef] [PubMed]

103. Liberman, M.C.; Kujawa, S.G. Cochlear synaptopathy in acquired sensorineural hearing loss: Manifestations and mechanisms. Hear. Res. 2017, 349, 138-147. [CrossRef] [PubMed]

104. Carlson, M.L. Cochlear Implantation in Adults. N. Engl. J. Med. 2020, 382, 1531-1542. [CrossRef] [PubMed]

105. Kujawa, S.G.; Liberman, M.C. Adding insult to injury: Cochlear nerve degeneration after "temporary" noise-induced hearing loss. J. Neurosci. 2009, 29, 14077-14085. [CrossRef] [PubMed]

106. Sergeyenko, Y.; Lall, K.; Liberman, M.C.; Kujawa, S.G. Age-related cochlear synaptopathy: An early-onset contributor to auditory functional decline. J. Neurosci. 2013, 33, 13686-13694. [CrossRef]

107. Rubel, E.W.; Furrer, S.A.; Stone, J.S. A brief history of hair cell regeneration research and speculations on the future. Hear. Res. 2013, 297, 42-51. [CrossRef] 
108. Cotanche, D.A. Regeneration of hair cell stereociliary bundles in the chick cochlea following severe acoustic trauma. Hear. Res. 1987, 30, 181-195. [CrossRef]

109. Cruz, R.M.; Lambert, P.R.; Rubel, E.W. Light microscopic evidence of hair cell regeneration after gentamicin toxicity in chick cochlea. Arch. Otolaryngol. Head Neck Surg. 1987, 113, 1058-1062. [CrossRef]

110. Corwin, J.T.; Cotanche, D.A. Regeneration of sensory hair cells after acoustic trauma. Science 1988, 240, 1772-1774. [CrossRef]

111. Ryals, B.M.; Rubel, E.W. Hair cell regeneration after acoustic trauma in adult Coturnix quail. Science 1988, $240,1774-1776$. [CrossRef]

112. Atkinson, P.J.; Huarcaya Najarro, E.; Sayyid, Z.N.; Cheng, A.G. Sensory hair cell development and regeneration: Similarities and differences. Development 2015, 142, 1561-1571. [CrossRef] [PubMed]

113. White, P.M.; Doetzlhofer, A.; Lee, Y.S.; Groves, A.K.; Segil, N. Mammalian cochlear supporting cells can divide and transdifferentiate into hair cells. Nature 2006, 441, 984-987. [CrossRef] [PubMed]

114. Warchol, M.E.; Lambert, P.R.; Goldstein, B.J.; Forge, A.; Corwin, J.T. Regenerative proliferation in inner ear sensory epithelia from adult guinea pigs and humans. Science 1993, 259, 1619-1622. [CrossRef]

115. Forge, A.; Li, L.; Corwin, J.T.; Nevill, G. Ultrastructural evidence for hair cell regeneration in the mammalian inner ear. Science 1993, 259, 1616-1619. [CrossRef]

116. Safety, Tolerability and Efficacy for CGF166 in Patients With Unilateral or Bilateral Severe-to-Profound Hearing Loss. Available online: https:/ /ClinicalTrials.gov/show/NCT02132130 (accessed on 15 April 2021).

117. Mulvaney, J.; Dabdoub, A. Atoh1, an essential transcription factor in neurogenesis and intestinal and inner ear development: Function, regulation, and context dependency. J. Assoc. Res. Otolaryngol. 2012, 13, 281-293. [CrossRef]

118. Zheng, J.L.; Gao, W.Q. Overexpression of Math1 induces robust production of extra hair cells in postnatal rat inner ears. Nat. Neurosci. 2000, 3, 580-586. [CrossRef]

119. Rutten, R.J. A First-in-Human Study of the Safety and Efficacy of a New Drug, a Gamma Secretase Inhibitor, to Treat People with Sensorineural Hearing Loss; ISRCTN: London, UK, 2017. [CrossRef]

120. McLean, W.J.; Hinton, A.S.; Herby, J.T.J.; Salt, A.N.; Hartsock, J.J.; Wilson, S.; Lucchino, D.L.; Lenarz, T.; Warnecke, A.; Prenzler, N.; et al. Improved Speech Intelligibility in Subjects With Stable Sensorineural Hearing Loss Following Intratympanic Dosing of FX-322 in a Phase 1b Study. Otol. Neurotol. 2021. [CrossRef]

121. Montcouquiol, M.; Corwin, J.T. Intracellular signals that control cell proliferation in mammalian balance epithelia: Key roles for phosphatidylinositol-3 kinase, mammalian target of rapamycin, and S6 kinases in preference to calcium, protein kinase C, and mitogen-activated protein kinase. J. Neurosci. 2001, 21, 570-580.

122. Witte, M.C.; Montcouquiol, M.; Corwin, J.T. Regeneration in avian hair cell epithelia: Identification of intracellular signals required for S-phase entry. Eur. J. Neurosci. 2001, 14, 829-838. [CrossRef]

123. Shu, Y.; Li, W.; Huang, M.; Quan, Y.Z.; Scheffer, D.; Tian, C.; Tao, Y.; Liu, X.; Hochedlinger, K.; Indzhykulian, A.A.; et al. Renewed proliferation in adult mouse cochlea and regeneration of hair cells. Nat. Commun. 2019, 10, 5530. [CrossRef]

124. Choi, Y.J.; Park, Y.J.; Park, J.Y.; Jeong, H.O.; Kim, D.H.; Ha, Y.M.; Kim, J.M.; Song, Y.M.; Heo, H.S.; Yu, B.P.; et al. Inhibitory effect of mTOR activator MHY1485 on autophagy: Suppression of lysosomal fusion. PLoS ONE 2012, 7, e43418. [CrossRef] [PubMed]

125. Li, X.J.; Doetzlhofer, A. LIN28B/let-7 control the ability of neonatal murine auditory supporting cells to generate hair cells through mTOR signaling. Proc. Natl. Acad. Sci. USA 2020, 117, 22225-22236. [CrossRef] [PubMed]

126. Xiong, W.; Wei, W.; Qi, Y.; Du, Z.; Qu, T.; Liu, K.; Gong, S. Autophagy is Required for Remodeling in Postnatal Developing Ribbon Synapses of Cochlear Inner Hair Cells. Neuroscience 2020, 431, 1-16. [CrossRef]

127. Kim, H.J.; Woo, H.M.; Ryu, J.; Bok, J.; Kim, J.W.; Choi, S.B.; Park, M.H.; Park, H.Y.; Koo, S.K. Conditional deletion of pten leads to defects in nerve innervation and neuronal survival in inner ear development. PLoS ONE 2013, 8, e55609. [CrossRef]

128. Bodmer, D. An update on drug design strategies to prevent acquired sensorineural hearing loss. Expert Opin. Drug Discov. 2017, 12, 1161-1167. [CrossRef]

129. Fang, B.; Xiao, H. Rapamycin alleviates cisplatin-induced ototoxicity in vivo. Biochem. Biophys. Res. Commun. 2014, $448,443-447$. [CrossRef]

130. Kim, Y.J.; Tian, C.; Kim, J.; Shin, B.; Choo, O.S.; Kim, Y.S.; Choung, Y.H. Autophagic flux, a possible mechanism for delayed gentamicin-induced ototoxicity. Sci. Rep. 2017, 7, 41356. [CrossRef]

131. Yuan, H.; Wang, X.; Hill, K.; Chen, J.; Lemasters, J.; Yang, S.M.; Sha, S.H. Autophagy attenuates noise-induced hearing loss by reducing oxidative stress. Antioxid. Redox Signal. 2015, 22, 1308-1324. [CrossRef]

132. Fu, X.; Sun, X.; Zhang, L.; Jin, Y.; Chai, R.; Yang, L.; Zhang, A.; Liu, X.; Bai, X.; Li, J.; et al. Tuberous sclerosis complex-mediated mTORC1 overactivation promotes age-related hearing loss. J. Clin. Investig. 2018, 128, 4938-4955. [CrossRef]

133. Altschuler, R.A.; Kabara, L.; Martin, C.; Kanicki, A.; Stewart, C.E.; Kohrman, D.C.; Dolan, D.F. Rapamycin Added to Diet in Late Mid-Life Delays Age-Related Hearing Loss in UMHET4 Mice. Front. Cell. Neurosci. 2021, 15, 658972. [CrossRef]

134. Altschuler, R.A.; Kanicki, A.; Martin, C.; Kohrman, D.C.; Miller, R.A. Rapamycin but not acarbose decreases age-related loss of outer hair cells in the mouse Cochlea. Hear. Res. 2018, 370, 11-15. [CrossRef] [PubMed]

135. He, Z.; Guo, L.; Shu, Y.; Fang, Q.; Zhou, H.; Liu, Y.; Liu, D.; Lu, L.; Zhang, X.; Ding, X.; et al. Autophagy protects auditory hair cells against neomycin-induced damage. Autophagy 2017, 13, 1884-1904. [CrossRef] [PubMed]

136. Guo, S.; Xu, N.; Chen, P.; Liu, Y.; Qi, X.; Liu, S.; Li, C.; Tang, J. Rapamycin Protects Spiral Ganglion Neurons from GentamicinInduced Degeneration In Vitro. J. Assoc. Res. Otolaryngol. 2019, 20, 475-487. [CrossRef] 
137. Ye, B.; Wang, Q.; Hu, H.; Shen, Y.; Fan, C.; Chen, P.; Ma, Y.; Wu, H.; Xiang, M. Restoring autophagic flux attenuates cochlear spiral ganglion neuron degeneration by promoting TFEB nuclear translocation via inhibiting MTOR. Autophagy 2019, 15, $998-1016$. [CrossRef]

138. Ebnoether, E.; Ramseier, A.; Cortada, M.; Bodmer, D.; Levano-Huaman, S. Sesn2 gene ablation enhances susceptibility to gentamicin-induced hair cell death via modulation of AMPK/mTOR signaling. Cell Death Discov. 2017, 3, 17024. [CrossRef]

139. Francis, S.P.; Katz, J.; Fanning, K.D.; Harris, K.A.; Nicholas, B.D.; Lacy, M.; Pagana, J.; Agris, P.F.; Shin, J.B. A novel role of cytosolic protein synthesis inhibition in aminoglycoside ototoxicity. J. Neurosci. 2013, 33, 3079-3093. [CrossRef]

140. Nicholas, B.D.; Francis, S.; Wagner, E.L.; Zhang, S.; Shin, J.B. Protein Synthesis Inhibition and Activation of the c-Jun N-Terminal Kinase Are Potential Contributors to Cisplatin Ototoxicity. Front. Cell. Neurosci. 2017, 11, 303. [CrossRef]

141. Yang, H.; Xie, X.; Deng, M.; Chen, X.; Gan, L. Generation and characterization of Atoh1-Cre knock-in mouse line. Genesis 2010, 48, 407-413. [CrossRef]

142. Ye, B.; Fan, C.; Shen, Y.; Wang, Q.; Hu, H.; Xiang, M. The Antioxidative Role of Autophagy in Hearing Loss. Front. Neurosci. 2018, 12, 1010. [CrossRef]

143. Fujimoto, C.; Iwasaki, S.; Urata, S.; Morishita, H.; Sakamaki, Y.; Fujioka, M.; Kondo, K.; Mizushima, N.; Yamasoba, T. Autophagy is essential for hearing in mice. Cell Death Dis. 2017, 8, e2780. [CrossRef]

144. Zhou, H.; Qian, X.; Xu, N.; Zhang, S.; Zhu, G.; Zhang, Y.; Liu, D.; Cheng, C.; Zhu, X.; Liu, Y.; et al. Disruption of Atg7-dependent autophagy causes electromotility disturbances, outer hair cell loss, and deafness in mice. Cell Death Dis. 2020, 11,913. [CrossRef] [PubMed]

145. Nuttall, A.L.; Wilson, T.; Omelchenko, I.; Shi, X.R. AMPK activation by AICAR induces mitochondrial biogenesis in the inner ear. FASEB J. 2012, 26. [CrossRef]

146. Foller, M.; Jaumann, M.; Dettling, J.; Saxena, A.; Pakladok, T.; Munoz, C.; Ruth, P.; Sopjani, M.; Seebohm, G.; Ruttiger, L.; et al. AMP-activated protein kinase in BK-channel regulation and protection against hearing loss following acoustic overstimulation. FASEB J. 2012, 26, 4243-4253. [CrossRef] [PubMed]

147. Hill, K.; Yuan, H.; Wang, X.; Sha, S.H. Noise-Induced Loss of Hair Cells and Cochlear Synaptopathy Are Mediated by the Activation of AMPK. J. Neurosci. 2016, 36, 7497-7510. [CrossRef] [PubMed]

148. McKay, S.E.; Yan, W.; Nouws, J.; Thormann, M.J.; Raimundo, N.; Khan, A.; Santos-Sacchi, J.; Song, L.; Shadel, G.S. Auditory Pathology in a Transgenic mtTFB1 Mouse Model of Mitochondrial Deafness. Am. J. Pathol. 2015, 185, 3132-3140. [CrossRef]

149. Zhao, J.; Li, G.; Zhao, X.; Lin, X.; Gao, Y.; Raimundo, N.; Li, G.L.; Shang, W.; Wu, H.; Song, L. Down-regulation of AMPK signaling pathway rescues hearing loss in TFB1 transgenic mice and delays age-related hearing loss. Aging 2020, 12, 5590-5611. [CrossRef]

150. Egan, D.F.; Shackelford, D.B.; Mihaylova, M.M.; Gelino, S.; Kohnz, R.A.; Mair, W.; Vasquez, D.S.; Joshi, A.; Gwinn, D.M.; Taylor, R.; et al. Phosphorylation of ULK1 (hATG1) by AMP-activated protein kinase connects energy sensing to mitophagy. Science 2011, 331, 456-461. [CrossRef]

151. Bach, M.; Larance, M.; James, D.E.; Ramm, G. The serine/threonine kinase ULK1 is a target of multiple phosphorylation events. Biochem. J. 2011, 440, 283-291. [CrossRef]

152. Wullschleger, S.; Loewith, R.; Hall, M.N. TOR signaling in growth and metabolism. Cell 2006, 124, 471-484. [CrossRef]

153. Howell, J.J.; Hellberg, K.; Turner, M.; Talbott, G.; Kolar, M.J.; Ross, D.S.; Hoxhaj, G.; Saghatelian, A.; Shaw, R.J.; Manning, B.D. Metformin Inhibits Hepatic mTORC1 Signaling via Dose-Dependent Mechanisms Involving AMPK and the TSC Complex. Cell Metab. 2017, 25, 463-471. [CrossRef]

154. Chang, J.; Jung, H.H.; Yang, J.Y.; Choi, J.; Im, G.J.; Chae, S.W. Protective role of antidiabetic drug metformin against gentamicin induced apoptosis in auditory cell line. Hear. Res. 2011, 282, 92-96. [CrossRef] [PubMed]

155. Chang, J.; Jung, H.H.; Yang, J.Y.; Lee, S.; Choi, J.; Im, G.J.; Chae, S.W. Protective effect of metformin against cisplatin-induced ototoxicity in an auditory cell line. J. Assoc. Res. Otolaryngol. 2014, 15, 149-158. [CrossRef] [PubMed]

156. Liang, Z.; Zhang, T.; Zhan, T.; Cheng, G.; Zhang, W.; Jia, H.; Yang, H. Metformin alleviates cisplatin-induced ototoxicity by autophagy induction possibly via the AMPK/FOXO3a pathway. J. Neurophysiol. 2021, 125, 1202-1212. [CrossRef] [PubMed]

157. Glutz, A.; Leitmeyer, K.; Setz, C.; Brand, Y.; Bodmer, D. Metformin Protects Auditory Hair Cells from Gentamicin-Induced Toxicity in vitro. Audiol. Neurootol. 2015, 20, 360-369. [CrossRef]

158. Oishi, N.; Kendall, A.; Schacht, J. Metformin protects against gentamicin-induced hair cell death in vitro but not ototoxicity in vivo. Neurosci. Lett. 2014, 583, 65-69. [CrossRef]

159. Gedik, O.; Dogan, R.; Babademez, M.A.; Karatas, E.; Aydin, M.S.; Kocyigit, A.; Esrefoglu, M.; Ozturan, O. Therapeutic effects of metformin for noise induced hearing loss. Am. J. Otolaryngol. 2020, 41, 102328. [CrossRef]

160. Muri, L.; Le, N.D.; Zemp, J.; Grandgirard, D.; Leib, S.L. Metformin mediates neuroprotection and attenuates hearing loss in experimental pneumococcal meningitis. J. Neuroinflamm. 2019, 16, 156. [CrossRef]

161. Hosoya, M.; Fujioka, M.; Sone, T.; Okamoto, S.; Akamatsu, W.; Ukai, H.; Ueda, H.R.; Ogawa, K.; Matsunaga, T.; Okano, H. Cochlear Cell Modeling Using Disease-Specific iPSCs Unveils a Degenerative Phenotype and Suggests Treatments for Congenital Progressive Hearing Loss. Cell Rep. 2017, 18, 68-81. [CrossRef]

162. Hosoya, M.; Saeki, T.; Saegusa, C.; Matsunaga, T.; Okano, H.; Fujioka, M.; Ogawa, K. Estimating the concentration of therapeutic range using disease-specific iPS cells: Low-dose rapamycin therapy for Pendred syndrome. Regen Ther. 2019, 10, 54-63. [CrossRef] 
163. Fujioka, M.; Akiyama, T.; Hosoya, M.; Kikuchi, K.; Fujiki, Y.; Saito, Y.; Yoshihama, K.; Ozawa, H.; Tsukada, K.; Nishio, S.Y.; et al. A phase I/IIa double blind single institute trial of low dose sirolimus for Pendred syndrome/DFNB4. Medicine 2020, 99 , e19763. [CrossRef]

164. Parmigiani, A.; Budanov, A.V. Sensing the Environment Through Sestrins: Implications for Cellular Metabolism. Int. Rev. Cell Mol. Biol. 2016, 327, 1-42. [CrossRef]

165. Zhang, C.; Sun, W.; Li, J.; Xiong, B.; Frye, M.D.; Ding, D.; Salvi, R.; Kim, M.J.; Someya, S.; Hu, B.H. Loss of sestrin 2 potentiates the early onset of age-related sensory cell degeneration in the cochlea. Neuroscience 2017, 361, 179-191. [CrossRef]

166. Bodmer, D.; Levano-Huaman, S. Sesn2/AMPK/mTOR signaling mediates balance between survival and apoptosis in sensory hair cells under stress. Cell Death Dis. 2017, 8, e3068. [CrossRef]

167. Jiang, H.; Sha, S.H.; Schacht, J. Kanamycin alters cytoplasmic and nuclear phosphoinositide signaling in the organ of Corti in vivo. J. Neurochem. 2006, 99, 269-276. [CrossRef]

168. Chung, W.H.; Pak, K.; Lin, B.; Webster, N.; Ryan, A.F. A PI3K pathway mediates hair cell survival and opposes gentamicin toxicity in neonatal rat organ of Corti. J. Assoc. Res. Otolaryngol. 2006, 7, 373-382. [CrossRef]

169. Sha, S.H.; Chen, F.Q.; Schacht, J. PTEN attenuates PIP3/Akt signaling in the cochlea of the aging CBA/J mouse. Hear. Res. 2010, 264, 86-92. [CrossRef]

170. Chen, J.; Yuan, H.; Talaska, A.E.; Hill, K.; Sha, S.H. Increased Sensitivity to Noise-Induced Hearing Loss by Blockade of Endogenous PI3K/Akt Signaling. J. Assoc. Res. Otolaryngol. 2015, 16, 347-356. [CrossRef]

171. Jadali, A.; Kwan, K.Y. Activation of PI3K signaling prevents aminoglycoside-induced hair cell death in the murine cochlea. Biol. Open 2016, 5, 698-708. [CrossRef]

172. Brand, Y.; Levano, S.; Radojevic, V.; Naldi, A.M.; Setz, C.; Ryan, A.F.; Pak, K.; Hemmings, B.A.; Bodmer, D. All Akt isoforms (Akt1, Akt2, Akt3) are involved in normal hearing, but only Akt2 and Akt3 are involved in auditory hair cell survival in the mammalian inner ear. PLoS ONE 2015, 10, e0121599. [CrossRef]

173. Yamahara, K.; Yamamoto, N.; Nakagawa, T.; Ito, J. Insulin-like growth factor 1: A novel treatment for the protection or regeneration of cochlear hair cells. Hear. Res. 2015, 330, 2-9. [CrossRef]

174. Rodriguez-de la Rosa, L.; Lassaletta, L.; Calvino, M.; Murillo-Cuesta, S.; Varela-Nieto, I. The Role of Insulin-Like Growth Factor 1 in the Progression of Age-Related Hearing Loss. Front. Aging Neurosci. 2017, 9, 411. [CrossRef] [PubMed]

175. Iwai, K.; Nakagawa, T.; Endo, T.; Matsuoka, Y.; Kita, T.; Kim, T.S.; Tabata, Y.; Ito, J. Cochlear protection by local insulin-like growth factor-1 application using biodegradable hydrogel. Laryngoscope 2006, 116, 529-533. [CrossRef] [PubMed]

176. Hayashi, Y.; Yamamoto, N.; Nakagawa, T.; Ito, J. Insulin-like growth factor 1 inhibits hair cell apoptosis and promotes the cell cycle of supporting cells by activating different downstream cascades after pharmacological hair cell injury in neonatal mice. Mol. Cell. Neurosci. 2013, 56, 29-38. [CrossRef] [PubMed]

177. Gao, L.; Kita, T.; Katsuno, T.; Yamamoto, N.; Omori, K.; Nakagawa, T. Insulin-Like Growth Factor 1 on the Maintenance of Ribbon Synapses in Mouse Cochlear Explant Cultures. Front. Cell. Neurosci. 2020, 14, 571155. [CrossRef] [PubMed]

178. Nakagawa, T.; Kumakawa, K.; Usami, S.; Hato, N.; Tabuchi, K.; Takahashi, M.; Fujiwara, K.; Sasaki, A.; Komune, S.; Sakamoto, T.; et al. A randomized controlled clinical trial of topical insulin-like growth factor-1 therapy for sudden deafness refractory to systemic corticosteroid treatment. BMC Med. 2014, 12, 219. [CrossRef] 